2021-01-30

\title{
Monitoring water quality changes and ornamental fish behaviour during commercial transport
}

\section{Vanderzwalmen, $\mathrm{M}$}

http://hdl.handle.net/10026.1/16425

10.1016/j.aquaculture.2020.735860

Aquaculture

Elsevier BV

All content in PEARL is protected by copyright law. Author manuscripts are made available in accordance with publisher policies. Please cite only the published version using the details provided on the item record or document. In the absence of an open licence (e.g. Creative Commons), permissions for further reuse of content should be sought from the publisher or author. 


\section{Monitoring water quality changes and}

\section{2 ornamental fish behaviour during}

\section{3 commercial transport}

Myriam Vanderzwalmen ${ }^{\mathrm{a}}$, Jason McNeill ${ }^{\mathrm{a}}$, Dorine Delieuvina ${ }^{\mathrm{a}}$, Simona Senes ${ }^{\mathrm{a}}$, Carrie Mullen ${ }^{\mathrm{a}}$, Iain

$5 \quad$ McLellan $^{\mathrm{a}}$, Peter Carey ${ }^{\mathrm{b}}$, Donna Snellgrove ${ }^{\mathrm{c}}$, Andy Foggo $^{\mathrm{d}}$, Mhairi E. Alexander ${ }^{\mathrm{a}}$, Fiona L.

6 Henriquez $^{\mathrm{a}}$ and Katherine A. Sloman ${ }^{\mathrm{a}}$

7 a Insitute of Biomedical and Environmental Health, School of Health and Life Sciences, University of

8 the West of Scotland, Paisley, UK

9 b Pets at Home, Handforth, Cheshire, UK

10 c WALTHAM Petcare Science Institute, Waltham-on-the-Wolds, LE14 4RT, Leicestershire, UK

11 d School of Biological and Marine Sciences, University of Plymouth, Plymouth, UK

correspondence

Myriam Vanderzwalmen, School of Health and Life Sciences, University of the West of Scotland,

Paisley PA1 2BE, UK. Tel: 00441418483371 Email: myriam.vanderzwalmen@ciwf.org 
19 Live transport of fishes is recognised as a major source of stress leading to poor welfare and mortality

20 within the ornamental fish industry. While previous studies have aimed to simulate the stressors

21 experienced by fishes during transport in the laboratory, there is little documented evidence of the

22 actual conditions experienced by fishes under commercial conditions. The aim of this study was to monitor water quality and fish health (physiology and behaviour) through a commercial supply chain for three popular freshwater ornamentals (neon tetra, oranda, variatus platy). Water samples were collected at nine stages of the supply chain beginning at arrival of the fishes at a UK wholesaler from Singapore through their recovery at the wholesaler, subsequent shipment to and recovery at retail stores. Water chemistry was recorded at various points in the transport chain and the water tested for common fish pathogens. Fish health parameters measured included mortality, injuries, waterborne cortisol and behavioural changes. Most water parameters were found to change significantly through the transport chain, including $\mathrm{pH}$, carbonate hardness $(\mathrm{KH})$, chloride $\left(\mathrm{Cl}^{-}\right)$, nitrate $\left(\mathrm{NO}_{3}{ }^{-}\right)$, sodium

$31\left(\mathrm{Na}^{+}\right)$, magnesium $\left(\mathrm{Mg}^{2+}\right)$, potassium $(\mathrm{K}+)$ and calcium $\left(\mathrm{Ca}^{2+}\right)$. Pathogens were detected in the water at each stage of transport, but no disease outbreaks were observed. Mortality was low and was not affected by transport stage. Neon tetras and orandas showed some behavioural changes during transport but the behaviour of variatus platys was more affected by transport stage. The findings of this study identify the changes in water quality experienced by fishes during commercial transport that are often over-looked in simulated studies and confirm the need for species-specific indicators of welfare during commercial transport. 
- First published study monitoring water quality and fish health (physiology and behaviour) through a commercial ornamental fish supply chain.

- Water quality was high overall but significant changes in water chemistry occurred between different stages of the supply chain.

- Potentially pathogenic microbes were detected in all samples but frequency of detection changed throughout the supply chain.

- Of the measured health indicators, behaviour was found to change the most between different stages of transport, and was also species-specific. 


\section{Introduction}

It is estimated that over 2 billion live ornamental fishes are transported annually (Monticini, 2010), with records of over 50 exporting countries and over 75 importing countries during 2012-2018 (United Nations, 2019). Fish are either wild caught or farm-reared and undergo multiple transport journeys throughout the supply chain (Olivier, 2003; Cohen, Valenti and Calado, 2013). The duration of international transport of ornamentals is on average $24 \mathrm{~h}$, but delays due to weather or customs procedures can cause an increase in transportation time (up to $72 \mathrm{~h}$ in some reported cases (Cole et al., 1999; Silva et al., 2015)). Within the UK, the majority of fish are imported from farms or wholesalers in developing countries in South-East Asia or South America (Leal et al., 2015). Transport can be a considerable source of stress in fish (Portz, Woodley and Cech, 2006; Sampaio and Freire, 2016), therefore legislation is in place to minimise the impact of live animal transport on welfare (e.g. Article 3 of Council Regulation (EC) No. 1/2005, UK), with use of transport containers that are appropriate for the species and comply with transport regulations (e.g. International Air Transport Association Live Animals Regulations, Ch. II, 4.1, Defra, 2006).

Over the duration of the transport, the quality of the containment water can degrade, resulting in sub-optimal conditions for the fish and high mortality if chemical parameters are not controlled (Harmon, 2009; Lim et al., 2003). Studies simulating commercial transport have shown that the most important water parameters to manage are dissolved oxygen (DO), temperature, $\mathrm{pH}$ and ammonia (Bower and Turner, 1982; Harmon, 2009; Ramírez-duarte et al., 2013; Sampaio and Freire, 2016; Silva et al., 2015; Teo et al., 1989). In simulated transport studies, fish are contained in water originating from the same source before, during and after the transport and any fluctuation in water quality is caused by the fish in the transport bag. However, within commercial settings, ornamental fishes are exposed to water from many different sources from their time at either aquaculture farms or in the wild, to their final arrival in a home aquarium. The water quality at different stages of the transport chain is likely to change abruptly, not only due to excretion from the fish but also from different water sources used by the various stakeholders and any measures used to control water quality and health of the fish. Elements such as calcium $\left(\mathrm{Ca}^{2+}\right)$, potassium $\left(\mathrm{K}^{+}\right)$, magnesium $\left(\mathrm{Mg}^{2+}\right)$, 
and sodium $\left(\mathrm{Na}^{+}\right)$are important for osmoregulation (Baldisserotto et al., 2007; Evans, 2008) whereas aluminium $(\mathrm{Al})$, copper $(\mathrm{Cu})$ and lead $(\mathrm{Pb})$ are toxic in excess to fishes (Shuhaimi-Othman et al., 2015; Spry and Wiener, 1991). Only a few studies have assessed changes in water quality and fish health for a complete transport chain (i.e. from the farm or time of capture to the retail store) and the range of water quality parameters measured in these studies was limited (Baldisserotto et al., 2014; Correia et al., 2011; Rodrigues et al., 2013).

Fish experiencing stress can become more susceptible to pathogenic microbes present in the water which can in turn result in a wide range of diseases (Crosby et al., 2005; Scholz, 1999; Yanong, 2010). Common pathogens of ornamental fishes are Mycobacterium spp. (causative agents of acute and chronic mycobacteriosis and include M. abscessus, . chelonae, M. fortuitum, M. haemophilum, M. marinum, M. peregrinum) (Gauthier and Rhodes, 2009; Prearo et al., 2004; Whipps et al., 2012), Vibrio spp. (causative agent of vibriosis, Thune, Stanley and Cooper, 1993; Roberts, Palmeiro and Weber, 2009), Flavobacterium columnare (causing columnaris disease, Decostere et al., 1999), Pseudomonas spp. (clinical signs of infection include ulcers, septicaemia, fin rot, red spot, Austin and Allen-Austin, 1985; Murphy and Lewbart, 1995), Aeromonas spp. (clinical signs include lesions, ulcers, tail or fin rot, haemorrhagic septicaemia, Citarasu et al., 2011; Roberts et al., 2009) and Streptococcus spp. (clinical signs include lethargy, poor appetite, erratic swimming, curved body shape, lesions, exophthalmia (also known as “pop-eye”), Hernández, Figueroa and Iregui, 2009; Amal and Zamri-Saad, 2011). Disease due to microbial pathogens is a widespread problem within the ornamental fish industry, and to our knowledge, no study has found the transport water of ornamental fishes to be pathogen-free. However, little research has been carried out assessing changes in the presence of pathogens at different stages of transport.

In addition to the lack of information on change in water quality during commercial transport, little is known about the cumulative effect of repeated transport and exposure to water of varying quality on the stress and welfare of ornamental fishes. Most studies assessing stress experienced in this context measure a range of stress indicators such as plasma cortisol, lactate and glucose levels (Ferreira et al., 2017; Inoue et al., 2005; Salbego et al., 2015) and the techniques involved are invasive 
103 (Abreu et al., 2014; Azambuja et al., 2011; Zanuzzo et al., 2017). However, in small ornamentals,

104 taking a blood sample in order to measure these indicators of stress often requires sacrificing the fish.

105 Less invasive indicators that could potentially be used include levels of cortisol in the water (Ellis et al., 2004; Ruane and Komen, 2003), changes in behaviour such as increased aggression (Braithwaite and Ebbesson, 2014; Huntingford et al., 2006; Weber, 2011), increased ventilation rate as an indicator of increased metabolic rate (Brydges et al., 2009; Huntingford et al., 2006; Portz et al., 2006) and darkening of the fish skin and eye (Backström et al., 2015; Freitas et al., 2014; Huntingford et al., 2006). However, we could find no study that assessed transport stress in ornamental fishes using noninvasive sampling techniques on a commercial scale.

In order to refine commercial practices, there is a need to understand the way that water quality can change across the transport chain and how this may influence ornamental fish health and behaviour. The aim of this study was to monitor water quality, presence of waterborne pathogens and ornamental fish behaviour over the course of a commercial transport chain, from arrival at a UK aquatics wholesaler following air transport from Singapore, through to post-transport recovery at retail stores.

\section{Materials and Methods}

\subsection{Study Animals}

The commercial transport of three ornamental fish species was studied to assess changes in water chemistry, waterborne pathogens and fish physiology and behaviour. The three species investigated were neon tetra (Paracheirodon innesi), small oranda goldfish (Carassius auratus) and yellow strain variatus platy (Xiphophorus variatus). Ten bags of each species were randomly selected and sampled over a period of 10 weeks starting from the fishes' arrival at a UK wholesaler. The fishes were all reared in farms in Singapore and prior to transport to the UK food was withheld for $24 \mathrm{~h}$ prior before fish were packed in polyethylene bags (neon tetra: 20 x 16.5 x $70 \mathrm{~cm}$; oranda and variatus platy: 35.5 x $70 \mathrm{~cm}$ ) containing water (neon tetra: 2.71 ; oranda: 1.41 and variatus platy: 41 ) and $25 \mathrm{ml}$ of liquid 
zeolite with the air space at the top of the bag filled with pure oxygen. The stocking density was 148

130 fish $\mathrm{l}^{-1}$ for neon tetra, 72 fish $\mathrm{l}^{-1}$ for oranda and 45 fish $\mathrm{l}^{-1}$ for variatus platy. The bags were then air-

131 tight sealed using a metal wire and placed into a polystyrene box insulated with newspapers along

132 with a variable number of other bags, then into a cardboard box. The bags of fish were air-shipped to

133 a UK airport where they went through customs and were then transported by road to an aquatics

134 wholesaler. The total transport duration was approximately $32 \mathrm{~h}$. On arrival at the wholesaler, water samples were taken from the bags for later analysis of water chemistry, waterborne pathogens and waterborne cortisol concentrations (see details below). Samples for water cortisol were frozen immediately on dry ice. Bags containing the remaining water and fish were then placed individually into aerated tanks $(76 \mathrm{~cm} \times 38 \mathrm{~cm} \times 38 \mathrm{~cm})$ containing 1001 of water at $24^{\circ} \mathrm{C}$. At this point the antibiotic tetracycline was added to all the tanks $\left(20 \mathrm{mg} \mathrm{l}^{-1}\right)$ so that it was fully dissolved by the time the fish were added. The bags were floated in the tank for approximately $30 \mathrm{~min}$ to allow temperatures to equilibrate, and then the bags were opened and briefly submerged to introduce tank water into the bag. Approximately 30 min later the fish were released into the tank. During recovery at the wholesaler, fish were kept under a 10:14 light/dark regime with a light fitted with a UV filter. Fish were fed three times daily ad libitum with Vitalis tropical or goldfish flake (World Feeds Ltd, UK) by members of wholesaler staff, who at this point would also remove any dead fish. On day 2 of recovery at the wholesaler, methylene blue $(0.1 \%)$ was added to all the tanks $\left(1 \mathrm{ml}^{-1}\right)$. The fish then spent 7 days at the wholesaler, where water samples were taken on days 1,2 and 5 for later analysis of water chemistry, prior to being transported to retail stores.

For transport to regional retail stores, the fish underwent the same packing process as for international transport, but no zeolite was added to the bag and food was not withheld prior to bagging. The loading density was 22 fish $1^{-1}$ for neon tetra, 7 fish $1^{-1}$ for oranda and 11 fish $\mathrm{l}^{-1}$ for variatus platy. Water samples were taken from each bag before it was sealed for later analysis of water chemistry, waterborne pathogens and water cortisol concentrations. Ten bags of each species were transported by road to five different retail stores (each store received two bags per species over a period of 10 weeks), with a journey time of less than $6 \mathrm{~h}$. On arrival at the retail store, water samples 
were again taken from each bag for water chemistry and water cortisol. Each bag was then placed into a separate recovery tank, and the fishes were acclimated using the same process as used at the wholesaler. Fish were kept under a $12 \mathrm{~h}$ light/dark regime. They were fed twice daily ad libitum (neon tetra: Love Fish tropical fish flakes, oranda: Love Fish coldwater pellets by Pets at Home Group Plc, variatus platy: Love Fish temperate fish flakes) by retail store staff, who at this point also removed any dead fish. Water samples were taken on days 1,2 and 5 of recovery at the stores for analysis of water chemistry and on day 5 only for analysis of waterborne pathogens. In addition to the collection of water samples, video recordings (30 min) were made using cameras (WiMiUS 4K 16MP Action) mounted on monopods and set at $720 \mathrm{P}$ (progressive scan) and $120 \mathrm{fps}$ (frames per second). This was carried out on a number of occasions: 1) upon arrival at the aquatics wholesaler, 2) on days 1,2 and 5 of recovery at the wholesaler, 3) before packing for transport to the retail stores, 4) on arrival at the retail stores and 5) on days 1,2 and 5 of recovery at the stores.

\subsection{Water Chemistry}

The water $\mathrm{pH}$, dissolved oxygen (DO) and temperature $\left({ }^{\circ} \mathrm{C}\right)$ were measured using a Hach HQ30d meter fitted with a Hach IntelliCAL ${ }^{\mathrm{TM}} \mathrm{pH}$ probe, and a Hach LDO101 DO probe. Carbonate hardness $(\mathrm{KH})$ was measured using a $\mathrm{KH}\left(\mathrm{d}^{\circ} \mathrm{KH}\right)$ test solution kit (API ${ }^{\circledR}$ Mars Fishcare, Solution ID \#3339). Water samples $(50 \mathrm{ml})$ for chemistry were collected in a homopolymer polypropylene sample tube and filtered using FilterMate ${ }^{\mathrm{TM}}, 0.45 \mu \mathrm{m}$ PDVF cartridge with PTFE prefilter before being frozen on dry ice at the time of collection for long-term storage at $-20^{\circ} \mathrm{C}$ until ion chromatography (IC), Inductively Coupled Plasma Optical Emission Spectrometry (ICP-OES) and ammonia assays were carried out.

A Dionex ICS-1100 ion chromatography system was used to determine chloride $\left(\mathrm{Cl}^{-}\right)$, phosphate $\left(\mathrm{PO}_{4}{ }^{3-}\right)$, sulphate $\left(\mathrm{SO}_{4}{ }^{2-}\right)$ and nitrate $\left(\mathrm{NO}_{3}{ }^{-}\right)$concentration. Conditions were: column: Dionex IonPac AS14a (4mm*250mm); delivery speed: $4 \mathrm{ml} \mathrm{min}^{-1}$; delay volume: $125 \mu$; flow rate: 1 $\mathrm{ml} \mathrm{min}{ }^{-1}$; eluents: $0.25 \mathrm{mM}$ sodium carbonate $\left(\mathrm{Na}_{2} \mathrm{CO}_{3}\right)$ and $0.25 \mathrm{mM}$ sodium bicarbonate $\left(\mathrm{NaHCO}_{3}\right)$ in a ratio of 8:1. Total run time was 20 min. For metal concentrations, a Perkin Elmer Avio-500 ICP- 
OES was used to determine $\mathrm{Al}, \mathrm{Ca}^{2+}, \mathrm{Cu}, \mathrm{K}^{+}, \mathrm{Mg}^{2+}, \mathrm{Na}^{+}$and $\mathrm{Pb}$. A multi-element standard (Fisher

183 Scientific, product code 1009-2633) was used for calibration. Filtered samples were acidified with

184 nitric acid (1\%) prior to analysis. The wavelengths used were: $\mathrm{Al}(396.153 \mathrm{~nm}), \mathrm{Ca}^{2+}(317 \mathrm{~nm}), \mathrm{Cu}$ (324.752 nm), $\mathrm{K}^{+}(766 \mathrm{~nm}), \mathrm{Mg}^{2+}(285 \mathrm{~nm}), \mathrm{Na}^{+}(589.592 \mathrm{~nm}), \mathrm{Pb}(220.353 \mathrm{~nm})$. (Bower and Holm-Hansen, 1980). Standards were made by a dilution of $1 \mathrm{mM}$ ammonium chloride $\left(\mathrm{NH}_{4} \mathrm{Cl}\right)$. Standards and samples were run in triplicate. The un-ionised ammonia $\left(\mathrm{NH}_{3}\right)$ content was calculated from the total ammonia nitrogen (TAN) values, the $\mathrm{pH}$ and temperature $\left({ }^{\circ} \mathrm{C}\right)(\mathrm{California}$ Water Boards Agency, 2011).

\subsection{Waterborne Pathogens}

Water $(50 \mathrm{ml})$ samples for microbiology analysis were collected in sterile falcon tubes and stored at $4^{\circ} \mathrm{C}$ until DNA extraction. Samples were centrifuged for $5 \mathrm{~min}$ at 5,000 $\mathrm{g}$ and filtered through a membrane filter $(0.45 \mu \mathrm{m}$ pore size $)$. The Metagenomic DNA isolation kit for water (Epicentre $^{\circledR}$, an Illumina company) was used to isolate DNA from the sample water and the DNA pellet was stored at $-20^{\circ}$ C. Polymerase chain reaction (PCR) was carried out on the isolated DNA with genus- or species-specific primers (Table 1) to record the occurrence of nine pathogens, which were recorded as present or absent. Sterile PCR tubes were used to mix $24 \mu \mathrm{l}$ of master mix and $1 \mu 1$ of sample. A negative control was carried out for each gel containing the master mix and $1 \mu 1$ of molecular water. The initial denaturation was $95^{\circ} \mathrm{C}$ for $2 \mathrm{~min}$. Cycling conditions for all primers were 35 cycles of $95^{\circ} \mathrm{C}$ for $30 \mathrm{~s}$, primer-specific annealing temperature for $45 \mathrm{~s}$ and $72^{\circ} \mathrm{C}$ for $1 \mathrm{~min}$. To ensure complete extension, the cycling conditions ended with a temperature rise to $72^{\circ} \mathrm{C}$ for $10 \mathrm{~min}$. $20 \mu \mathrm{l}$ of each sample/negative control was analysed by gel electrophoresis on an ethidium bromide stained $2 \%$ agarose gel. 
Table 1. Pathogens tested for presence/absence in the water and PCR master mix composition.

\begin{tabular}{|c|c|c|c|}
\hline Primer & Forward Sequence (5'- 3') & Reverse Sequence (5'- 3') & Annealing \\
\hline Aeromonas spp. & 5'-TCCGTTGGATATGGCTCTTC-3' & 5'-GCGTACCACGATGTCTGAA-3' & $58^{\circ} \mathrm{C}$ \\
\hline Pseudomonas spp. & 5'-GACGGGTGAGTAATGCCTA-3' & 5'-CACTGGTGTTCCTTCCTATA-3' & $63^{\circ} \mathrm{C}$ \\
\hline Flavobacterium columnare & 5'-GCAGGATGACGGTCCTATGG-3' & 5'-TTAACCTGACACCTCACGGC-3' & $58^{\circ} \mathrm{C}$ \\
\hline Streptococcus spp. & 5'-GTACAGTTGCTTCAGGACGTATC-3' & 5'-ACGTTCGATTTCATCACGTTG-3' & $52^{\circ} \mathrm{C}$ \\
\hline Mycobacterium spp. & 5'- CCTTTCTAAGGAGCACCACGA-3' & 5'-TTGCTTAGATGCTCGCAACC-3' & $58^{\circ} \mathrm{C}$ \\
\hline Escherichia coli & 5'-CGGACGGGTGAGTAATGTCT-3' & 5'-GTTAGCCGGTGCTTCTTCTG-3' & $65^{\circ} \mathrm{C}$ \\
\hline Acanthamoeba spp. & 5'-GGCCCAGATCGTTTACCGTGAA-3' & 5'-TCTCACAAGCTGCTAGGGGAGTCA-3' & $62^{\circ} \mathrm{C}$ \\
\hline Vibrio anguillarum & 5'-AAGAAGCACCGGCTAACTCC-3' & 5'-CCATGCAGCACCTGTCTTAC-3' & $53^{\circ} \mathrm{C}$ \\
\hline Staphylococcus aureus & 5'-GCGATTGATGGTGATACGGTT-3' & 5'-CAAGCCTTGACGAACTAAAGC-3' & $55^{\circ} \mathrm{C}$ \\
\hline
\end{tabular}


A range of measures were taken to assess potential stress experienced by the fishes during transport and recovery. Physiological indicators of stress were studied by measuring levels of waterborne cortisol and ventilation rate. Behavioural signs of stress were recorded by observing stress-related behaviours displayed by the fish. Mortality levels were recorded daily by wholesaler and retail store staff. The physical condition of the fish was assessed by recording any visible injuries to both the body and fins using the video recordings collected for behavioural analysis. In addition, the eye colour of fish was calculated from video images to determine if it could be used as an indicator of stress, as has been done in other fish species (Cruz and Tauli, 2015; Freitas et al., 2014; Suter and Huntingford, 2002; Volpato et al., 2003).

\subsubsection{Waterborne Cortisol}

Water samples $(100 \mathrm{ml})$ were collected in homopolymer polypropylene sample tubes, frozen immediately on dry ice and stored at $-20^{\circ} \mathrm{C}$ until further analysis. Sep-Pak ${ }^{\circledR}$ Light $\mathrm{C} 18$ cartridges were primed with $1 \mathrm{ml}$ methanol (100\%) followed by $1 \mathrm{ml}$ of double distilled water. Cortisol was extracted through the cartridges using a vacuum pump with a maximum flow rate of $1 \mathrm{ml} \mathrm{min}^{-1}$, followed by $1 \mathrm{ml}$ of methanol (20\%), then $1 \mathrm{ml}$ of methanol (100\%) to elute the cortisol. Methanol was evaporated using a nitrogen sample evaporator (Biotage ${ }^{\circledR}$ ) at $45^{\circ} \mathrm{C}$ and reconstituted in $250 \mu 1$ assay buffer. Cortisol concentrations were then measured using an enzyme-linked immunosorbent assay (ELISA) cortisol plate assay (Enzo Prod. No. ADI-900-071) with all samples and standards run in duplicate. Cortisol concentrations were adjusted for stocking density and duration of transport and expressed as cortisol released per fish per hour of transport $\left(\mathrm{pg} \mathrm{fish}^{-1} \mathrm{~h}^{-1}\right)$.

\subsubsection{Behaviour}

Behavioural Observation Research Interactive Software (BORIS) (Friard and Gamba, 2016) was used to analyse behaviour displayed by the fish (Table 2). To determine reliability of analyses, 
232 between observers (Kendall's W coefficient: $0.96, \mathrm{p}<0.01$ ). Randomly selected individual fish were

233 tracked for $3 \mathrm{~min}$, and this was repeated consecutively from the start to the end of the video such that

23410 individuals were tracked. Displayed behaviours for each focal fish were totalled to obtain either a

235 bag or tank score depending on the stage of transport. For neon tetras, only gasping, crowding and

236 group formation were visible on the videos due to the small size of the fish. On arrival at the

237 wholesaler while the fish were still in the bag, only gasping, crowding and group formation were

238 measured due to visibility at high stocking densities. Only behaviours that were visible at specific

239 stages of transport were included in statistical analyses. 
Table 2. Ethogram of the behaviours recorded.

\begin{tabular}{|c|c|c|}
\hline Behaviour & Description & Relation to welfare \\
\hline Gasping & $\begin{array}{l}\text { Approximate per cent of fish gasping at the } \\
\text { surface of the water. }\end{array}$ & $\begin{array}{l}\text { Gasping behaviour indicates low-quality water, specifically, low levels of DO } \\
\text { (Kramer, 1987). }\end{array}$ \\
\hline Crowding & $\begin{array}{l}\text { Approximate per cent of fish grouped close } \\
\text { (within } 1 \text { body length) together and } \\
\text { swimming in the same direction. }\end{array}$ & $\begin{array}{l}\text { Crowding increases with stress and can be a result of a perception of threat } \\
\text { (Schreck et al., 1997). }\end{array}$ \\
\hline $\begin{array}{l}\text { Group } \\
\text { formation }\end{array}$ & $\begin{array}{l}\text { All fishes in the tank forming multiple } \\
\text { schools with } 30 \mathrm{~cm} \text { between the groups. }\end{array}$ & $\begin{array}{l}\text { The polarization of schools has been suggested to occur as a trade-off between } \\
\text { predation risk and optimal foraging (Delgado De Carvalho et al., 2007). }\end{array}$ \\
\hline Biting & $\begin{array}{l}\text { Occurrence of fish biting or nipping a } \\
\text { conspecific. }\end{array}$ & $\begin{array}{l}\text { Biting can cause injuries and may lead to death. It is also a sign of aggression, or } \\
\text { sub-optimal feeding (Håstein et al., 2005; Kalueff et al., 2013; Martins et al., } \\
\text { 2012). }\end{array}$ \\
\hline $\begin{array}{l}\text { Erratic } \\
\text { swimming }\end{array}$ & $\begin{array}{l}\text { Occurrence of rapid swimming and } \\
\text { direction change in the absence of being } \\
\text { chased. }\end{array}$ & $\begin{array}{l}\text { Erratic swimming is an indicator of elevated stress, distress or pathogenic } \\
\text { condition and may be used as a sign of bad welfare (Conte, 2004; Håstein et al., 2005; } \\
\text { White et al., 2017). }\end{array}$ \\
\hline $\begin{array}{l}\text { Latency to } \\
\text { feed }\end{array}$ & $\begin{array}{l}\text { Duration (s) from the time food is dropped } \\
\text { in the tanks to the time } 90 \% \text { of the fish are } \\
\text { feeding. }\end{array}$ & $\begin{array}{l}\text { Latency to feed can indicate a reduced motivation to feed, an increased perception } \\
\text { of risk to feed, reduced confidence to approach food (Magurran and Pitcher, 1983; } \\
\text { Mikheev et al., 1994; Saxby et al., 2010). }\end{array}$ \\
\hline Freezing & Duration (s) fish spend immobile. & $\begin{array}{l}\text { Freezing is considered a fear and stress-related behaviour (Braithwaite and } \\
\text { Salvanes, 2005; Koolhaas et al., 1999). }\end{array}$ \\
\hline $\begin{array}{l}\text { Ventilation } \\
\text { rate }\end{array}$ & $\begin{array}{l}\text { Measured by visually counting } 20 \\
\text { successive opercular or buccal movements, } \\
\text { measuring the elapsed time and then } \\
\text { calculating the frequency per minute (based } \\
\text { on Alvarenga and Volpato, 1995). }\end{array}$ & $\begin{array}{l}\text { Ventilation rate can increase as a result of aquaculture procedures or stressors and } \\
\text { is a highly sensitive mechanism involved in stress coping strategies (Barreto and } \\
\text { Volpato, 2004; Martins et al., 2012). }\end{array}$ \\
\hline
\end{tabular}


Any mortality was recorded daily by staff at the wholesaler and retail stores. From the recorded videos used for behavioural analysis, three still frames (one showing the full left flank, one showing the full right flank and one showing the tail) were taken to assess the physical condition of each of the 10 focal fish. Body injuries were recorded based on the following criteria: (0) no visual injuries; (1) single minor non-life-threatening injury; (2) multiple minor non-life-threatening injuries; (3) major life-threatening injury. Injuries to fins were recorded as follows: (0) no visible injury; (1); small section of fin missing; (2) large section of fin missing or shortening of the fin; (3) fin missing (Deng et al., 2005; Neitzel et al., 2004). The scores for fin injury and body injury were summed to obtain an overall injury score; these injuries were recorded for each fish and combined to obtain an injury score for all the fish transported together. Eye colour was measured only during recovery at the store because the methylene blue added to the water at the wholesaler affected the colouring of the water. Eye colour was assessed from one still frame per focal fish for oranda and variatus platy but not for neon tetra due to their small size. Photoshop Elements 15 was used to select the image of the iris. MatLab was used to determine the number of pixels on the grey scale pixel intensity scale (from 0-64 = black, $65-128=$ dark grey, 129-192 = light grey, 193-255 = white). The percentage pixel of each intensity was calculated using the following equation:

$$
\frac{\text { number of pixels at intensity }}{\text { total number of pixels }} \times 100
$$

This study was approved by the University of the West of Scotland Ethics Committee as well as the Animal Welfare Ethics Review Board at the Waltham Petcare Science Institute. The samples collected in this study were collected non-invasively as part of routine transport of the fish for commercial purposes. 
Statistical analyses were carried out based on Bolker et al. (2009) using R ver. 3.6.1. (R Core

Team, 2018). First, whether water quality parameters, behavioural and physiological measures and the percentage of water samples containing each pathogen differed between each stage of transport was considered. Error structures including homogeneity of variances for linear and generalized linear models were determined by visual inspection of residuals and QQ plots (R Core Team, 2018). The normally distributed response variables were fitted to a general linear mixed model with stage of transport (i.e. arrival at wholesaler, day 1 at wholesaler etc.) and species as fixed factors, and with sampling location (i.e. wholesaler and specific stores) and bag number (out of 10 replicate blocks for each species) as random terms using the lme function from the nlme package (Pinheiro et al., 2018). For non-normally distributed response variables, the log and square root functions were applied. The transformation was tested by checking the distribution of the residuals as described above and the best transformation was selected. If the data could not be transformed to normality, a generalised linear mixed model was carried out using Poisson family from the lme4 package (Bates et al., 2015) with random explanatory variables designated as before and the data were checked for over-dispersion using the blmeco package (Korner-Nievergelt et al., 2015). Fixed explanatory variables that did not significantly improve the fit of the model based on delta AIC in stepAIC were removed from the model (Venables and Ripley, 2002). Percentage data were expressed as proportions and a binomial generalised linear mixed model (GLMM) was carried out with the fixed and random variables as described above. Model simplification was performed using delta AIC as previously described and P values for fixed terms derived from Chi-square log-likelihood test. The significance of the covariates was tested by ANOVA (using the Anova function in the car package) (Fox and Weisberg, 2011; Pinheiro et al., 2018). Due to the large number of comparisons, a Bonferroni correction was carried out using the emmeans package (Lenth et al., 2019). The figures were created using the ggplot2 package (Wickham, 2016). model analysis. For each response variable a general or generalised linear model was carried out as 
described above with presence of each pathogen set as explanatory variables. Model selection via AIC was carried out as described above to identify pathogens that significantly affected the response variable. T-tests were carried out for each selected pathogen to determine the effect of pathogen presence on response behaviour.

Following separate analyses into changes in water quality and welfare between the stages of transport, the influence of water quality on welfare (i.e. behaviour and physiology measures) was considered. To do this, distance-based linear models (DistLM) were used to determine if water quality influenced behaviour. DistLM analyses were carried out using PRIMER 7 software (Clarke and Gorley, 2015) with the PERMANOVA+ add-on (Anderson, Gorley and Clarke, 2016). The chemistry data were standardised to a mean of 0 and standard deviation of 1 , and a resemblance analysis was carried out for the chemistry and behavioural data to measure distance using Euclidean distance. DistLM was carried out step-wise to select for the optimum model based on the AIC.

\section{Results}

The water chemistry parameters measured were each analysed for differences between species and between each stage of the transport chain. DO was significantly affected by both species and stage of transport (Fig. 1A; Table 3).

Table 3. ANOVA result for each recorded water quality parameter for stage of transport, species and in the interaction between stage of transport and species showing $\mathrm{F}$ values, degrees of freedom (df), and $\mathrm{p}$ values.

\begin{tabular}{|l|l|l|l|}
\hline & Transport Stage & Species & Transport Stage*Species \\
\hline DO & $\mathrm{F}_{8,218}=132.43, \mathrm{p}<0.001$ & $\mathrm{~F}_{8,218}=12.69, \mathrm{p}<0.001$ & $\mathrm{~F}_{16,218}=4.88, \mathrm{p}<0.001$ \\
\hline Temperature & $\mathrm{F}_{8,220}=11.5, \mathrm{p}<0.001$ & $\mathrm{~F}_{2,220}=42.3, \mathrm{p}<0.001$ & $\mathrm{~F}_{16,220}=9.3, \mathrm{p}<0.001$ \\
\hline $\mathrm{pH}$ & $\mathrm{F}_{8,220}=11.175, \mathrm{p}<0.001$ & $\mathrm{~F}_{2,220}=7.78, \mathrm{p}=0.001$ & $\mathrm{~F}_{16,220}=1.43, \mathrm{p}=0.214$ \\
\hline
\end{tabular}




\begin{tabular}{|l|l|l|l|}
\hline $\mathrm{KH}$ & $\mathrm{F}_{8,238}=3.58, \mathrm{p}=0.002$ & $\mathrm{~F}_{2,236}=0.503, \mathrm{p}=0.781$ & $\mathrm{~F}_{61,220}=0.378, \mathrm{p}=0.998$ \\
\hline TAN & $\mathrm{F}_{8,220}=23.64, \mathrm{p}<0.001$ & $\mathrm{~F}_{2,220}=9.658, \mathrm{p}<0.001$ & $\mathrm{~F}_{16,220}=4.557, \mathrm{p}<0.001$ \\
\hline $\mathrm{NH}_{3}$ & $\mathrm{~F}_{8,238}=2.59, \mathrm{p}=0.012$ & $\mathrm{~F}_{2,236}=0.245, \mathrm{p}=0.874$ & $\mathrm{~F}_{16,220}=2.3215, \mathrm{p}=0.008$ \\
\hline $\mathrm{NO}_{3}{ }^{-}$ & $\mathrm{F}_{8,235}=25.226, \mathrm{p}<0.001$ & $\mathrm{~F}_{2,235}=3.417, \mathrm{p}=0.059$ & $\mathrm{~F}_{16,219}=1.106, \mathrm{p}=0.543$ \\
\hline $\mathrm{SO}_{4}{ }^{2-}$ & $\mathrm{F}_{8,219}=11.076, \mathrm{p}<0.001$ & $\mathrm{~F}_{2,219}=4.376, \mathrm{p}=0.025$ & $\mathrm{~F}_{16,219}=4.153, \mathrm{p}<0.001$ \\
\hline $\mathrm{Cl}^{-}$ & $\mathrm{F}_{8,238}=20.49, \mathrm{p}<0.01$ & $\mathrm{~F}_{2,236}=0.841, \mathrm{p}=0.571$ & $\mathrm{~F}_{16,202}=2.691, \mathrm{p}=0.018$ \\
\hline $\mathrm{PO}_{4}{ }^{3-}$ & $\mathrm{F}_{8,236}=4.73, \mathrm{p}<0.01$ & $\mathrm{~F}_{2,234}=1.448, \mathrm{p}=0.237$ & $\mathrm{~F}_{16,218}=0.705, \mathrm{p}=0.879$ \\
\hline $\mathrm{Na}^{+}$ & $\mathrm{F}_{8,236}=7.21, \mathrm{p}<0.01$ & $\mathrm{~F}_{2,236}=3.34, \mathrm{p}=0.071$ & $\mathrm{~F}_{16,220}=0.472, \mathrm{p}=0.998$ \\
\hline $\mathrm{Ca}^{2+}$ & $\mathrm{F}_{8,263}=4.421, \mathrm{p}<0.001$ & $\mathrm{~F}_{2,236}=4.228, \mathrm{p}=0.035$ & $\mathrm{~F}_{16,220}=0.267, \mathrm{p}=0.998$ \\
\hline $\mathrm{K}^{+}$ & $\mathrm{F}_{8,220}=0.697, \mathrm{p}=0.83$ & $\mathrm{~F}_{2,220}=5.29, \mathrm{p}=0.012$ & $\mathrm{~F}_{16,220}=0.539, \mathrm{p}=0.998$ \\
\hline $\mathrm{Mg}^{2+}$ & $\mathrm{F}_{8,220}=0.63, \mathrm{p}=0.875$ & $\mathrm{~F}_{8,244}=9.46, \mathrm{p}<0.01$ & $\mathrm{~F}_{16,220}=0.811, \mathrm{p}=0.826$ \\
\hline
\end{tabular}

DO was higher on arrival at both the wholesaler and the retail store and was higher in the neon

317 tetra water on arrival at the wholesaler than in the oranda and variatus platy water. DO remained

318 higher in the neon tetra tanks than in the oranda tanks on day 1 and 2 of recovery at the wholesaler

319 (Fig. 1A). Water temperature was affected by transport stage (Table 3) and species. The water temperature experienced by neon tetras did not change throughout their transport, whereas both orandas and variatus platy experienced a decrease in temperature at the retail stores (Fig. 1B). For all species, water $\mathrm{pH}$ was significantly lower on arrival at the wholesaler than at subsequent transport stages and throughout the $\mathrm{pH}$ in the neon tetra water was higher than that of oranda water (Fig. 2A). $\mathrm{KH}$ was significantly higher on arrival at the wholesaler than in the water fish were packed in for transport to the retail stores (Fig. 2B; Table 3). Species and the interaction between species and transport stage was not significant (Table 3). 
TAN was significantly affected by stage of transport and species and the two factors interacted significantly (Fig. 3A; Table 3). TAN water levels on arrival at the wholesaler were significantly higher in neon tetra and oranda bags than during the subsequent transport stages (Fig. 3A). On day 1 of recovery at the store, TAN was higher in variatus platy tanks than in neon tetra tanks; on day 2 of recovery at the store, TAN was higher in oranda tanks than in neon tetra tanks (Fig. 3A). $\mathrm{NH}_{3}$ was lower during recovery at the wholesaler than during the other transport stages with inter-specific differences in $\mathrm{NH}_{3}$ dependent upon transport stage (Fig. 3B; Table 3).

There was a significant effect of transport stage on $\mathrm{NO}_{3}{ }^{-}$and the effect of species approached

\subsection{Waterborne Pathogens}


The presence/absence of pathogens in water samples taken at each stage of transport was analysed across all species of fish. The percentage of samples that contained Aeromonas spp. was significantly higher on arrival at the wholesaler than in the water samples when fish were packed for transport to retail stores and on day 5 of recovery at the store $\left(X^{2}=31.093, \mathrm{df}=2, \mathrm{p}<0.0001\right.$; Fig. 6A). Pseudomonas spp. was present in significantly more samples on arrival at the wholesaler than at packing for transport to retail stores and the number of positive samples was significantly lower again on day 5 of recovery at the stores $\left(X^{2}=30.094, \mathrm{df}=2, \mathrm{p}<0.0001\right.$; Fig. 6B $)$. Mycobacterium spp. presence significantly decreased between arrival at the wholesaler and day 5 post-transport at the retail store $\left(X^{2}=55.735, \mathrm{df}=2, \mathrm{p}<0.0001 ;\right.$ Fig. 6C). Mycobacterium spp. was present in every sample at packing for transport to retail stores, this caused a lack of variation and post-hoc testing for this data point was not possible. The number of positive samples for Acanthamoeba spp. (21.59\% $\pm 41.38 \mathrm{SD})$, E. coli $(97.73 \% \pm 14.99 \mathrm{SD})$, F. columnare $(95.45 \% \pm 20.94 \mathrm{SD})$, Streptococcus spp. (54.54\% $\pm 50.01 \mathrm{SD})$, S. aureus $(21.59 \% \pm 41.38 \mathrm{SD})$ and $V$. anguillarum $(98.86 \% \pm 10.66 \mathrm{SD})$ did not change significantly through the three tested stages of transport.

\subsection{Fish physiology and behaviour}

In neon tetras only two behaviours showed significant changes through transport stage. Group formation behaviour was greater on day two of recovery at the wholesaler than at the other stages of transport, except for day 1 of recovery at the wholesaler and at the store $\left(\mathrm{F}_{8,60}=4.711, \mathrm{p}=0.004\right.$; Fig. 7A). Latency to feed was significantly lower during recovery at the retail stores than during recovery at the wholesaler $\left(\mathrm{F}_{3,33}=19.404, \mathrm{p}<0.001\right.$; Fig. $\left.7 \mathrm{~B}\right)$. In oranda, the occurrence of erratic swimming was highest on day 5 of recovery at the store $\left(\mathrm{F}_{1,8}=5.66, \mathrm{p}=0.003 ;\right.$ Fig. 8$)$. In variatus platy, occurrence of erratic swimming significantly decreased between day 1 of recovery at the wholesaler and day 2 and 5 of recovery at the wholesaler (Fig. 9A). Variatus platy displayed significantly less erratic swimming during recovery at the store than at the wholesaler $\left(\mathrm{F}_{6,38}=10.269, \mathrm{p}=<0.001\right.$; Fig. 9A $)$. Biting behaviour was significantly affected by the transport stage with a general increase seen in the occurrence of biting behaviour through transport stages and the occurrence of biting was significantly higher at day 5 of recovery at the store than the previous stages $\left(F_{6,38}=7.618, p=<0.001\right.$; Fig. 9B $)$. The 
occurrence of freezing behaviour was significantly higher on day 1 of recovery at the store than all the

381 other recorded stages of transport, except for day 2 of recovery at the store $\left(\mathrm{F}_{6,38}=4.569, \mathrm{p}=0.002\right.$; Fig.

382 9C). Erratic swimming, biting and freezing behaviour could not be observed on arrival at the

383 wholesaler or the store, therefore these time points were excluded from the analysis. No other

384 significant changes were recorded in behavioural and physiological measures (Supplementary

385 Material, Table 1). In orandas, the presence of Mycobacteria spp. in the water resulted in a

386 significantly darker eye colour (t-test=2.611, p=0.026; Fig. 10). No other pathogen was found to have

387 a significant effect on any of the recorded behaviour and health measures $(p<0.05)$.

388 Distance-based linear models revealed that, in neon tetra, $56.03 \%$ of variation in the latency to

389 feed was associated with $\mathrm{NO}_{3}{ }^{-}, \mathrm{Cl}^{-}, \mathrm{Na}^{+}, \mathrm{PO}_{4}{ }^{3-}$ and $\mathrm{Mg}^{2+}$ concentrations (Table 4) changes in group

390 formation were not attributable to water chemistry. Copper and TAN explained $32.19 \%$ of the

391 variation in erratic swimming behaviour in oranda whereas in variatus platy, $62.52 \%$ of variation in

392 erratic swimming was explained by $\mathrm{DO}, \mathrm{Cl}^{-}, \mathrm{NO}_{3}{ }^{-}$and $\mathrm{K}^{+}$(Table 3). Variation in biting behaviour

393 (35.26\%) displayed by variatus platy was explained by temperature, $\mathrm{pH}$ and $\mathrm{NH}_{3}$ and variation in

394 freezing behaviour (18.15\%) was explained by $\mathrm{NO}_{3}{ }^{-}$and $\mathrm{pH}$ (Table 4). 
Table 4. Results for behavioural variation in neon tetra, oranda and variatus platy showing the chemical parameters selected via DistLM indicating Pseudo-F, $p$ value and residual degrees of 398 freedom (df).

\begin{tabular}{|c|c|c|c|c|c|c|}
\hline Species & Behaviour & DistLM & Contribution (\%) & Pseudo-F & $\mathrm{p}$ value & Residual df \\
\hline \multicolumn{7}{|c|}{ Neon tetra } \\
\hline & $\begin{array}{l}\text { Latency to } \\
\text { feed }\end{array}$ & & & & & \\
\hline & & $\mathrm{NO}_{3}^{-}$ & 28.625 & 22.459 & 0.001 & 56 \\
\hline & & $\mathrm{Cl}^{-}$ & 14.899 & 14.510 & 0.001 & 55 \\
\hline & & $\mathrm{Na}^{+}$ & 5.515 & 5.843 & 0.013 & 54 \\
\hline & & $\mathrm{PO}_{4}^{3-}$ & 3.585 & 4.010 & 0.044 & 53 \\
\hline & & $\mathrm{Mg}^{2+}$ & 3.413 & 4.037 & 0.056 & 52 \\
\hline \multicolumn{7}{|l|}{ Oranda } \\
\hline & $\begin{array}{l}\text { Erratic } \\
\text { swimming }\end{array}$ & & & & & \\
\hline & & $\mathrm{Cu}$ & 29.323 & 33.191 & 0.005 & 80 \\
\hline & & TAN & 2.872 & 3.346 & 0.059 & 79 \\
\hline \multirow{2}{*}{\multicolumn{7}{|c|}{$\begin{array}{l}\text { Variatus } \\
\text { platy }\end{array}$}} \\
\hline & & & & & & \\
\hline & & DO & 41.493 & 41.843 & 0.001 & 59 \\
\hline & & $\mathrm{Cl}^{-}$ & 16.240 & 22.285 & 0.001 & 58 \\
\hline & & $\mathrm{NO}_{3}^{-}$ & 2.508 & 3.596 & 0.062 & 57 \\
\hline & & $\mathrm{K}^{+}$ & 2.283 & 3.412 & 0.071 & 56 \\
\hline & Biting & & & & & \\
\hline & & temperature & 16.965 & 12.462 & 0.002 & 61 \\
\hline & & $\mathrm{pH}$ & 13.253 & 11.396 & 0.004 & 60 \\
\hline & & $\mathrm{NH}_{3}$ & 2.779 & 2.447 & 0.116 & 59 \\
\hline & & $\mathrm{Cl}^{-}$ & 2.262 & 2.026 & 0.133 & 58 \\
\hline & Freezing & & & & & \\
\hline & & $\mathrm{NO}_{3}^{-}$ & 9.699 & 6.444 & 0.026 & 60 \\
\hline & & $\mathrm{pH}$ & 8.454 & 6.094 & 0.022 & 59 \\
\hline
\end{tabular}




\section{Discussion}

The aim of this study was to record a range of water quality and health (physiological and behavioural) parameters throughout the stages of commercial transport for neon tetra, oranda and variatus platy. This is the first study to our knowledge that has collected these measures through multiple stages of commercial transport. Overall, we found that water quality fluctuated greatly, albeit within safe levels for the fishes, throughout the stages of the recorded supply chain; all of the tested pathogens were present within this supply chain at different levels. The fluctuation in water chemistry parameters recorded in this study could be a source of stress for the fishes within the ornamental trade that is rarely if ever considered. Out of the recorded stress measures, behaviour was found to be the most sensitive, changing the most across stages of transport. Behavioural changes have never been tested as an indicator of stress in ornamental fish studies which often employ invasive or lethal methodologies.

Water quality was high from arrival at the wholesaler to recovery at the stores. Throughout the stages of transport, oxygen was on average above $100 \%$ saturation. The mean water $\mathrm{pH}$ was 6.7 with a few instances where $\mathrm{pH}$ dropped below 5.5. The range in water $\mathrm{pH}$ between stores was large due to the geographical distribution of the stores. Small daily fluctuations in $\mathrm{pH}$ are unlikely to have a long term effect on fish, although this will be species-dependent (Cecil, 1999; Oliveira et al., 2008; Roberts and Palmeiro, 2008). High levels of $\mathrm{NH}_{3}$ are toxic to fishes and can lead to mortality (LC50 toxicity $\sim 2.79 \mathrm{mg} \mathrm{l}^{-1}$ in freshwater fishes at $\mathrm{pH} 8$ and $20^{\circ} \mathrm{C}$ based on 32 freshwater species but LC50 is different between species) (Randall and Tsui, 2002, USEPA, 1984). Average levels of $\mathrm{NH}_{3}$ were $0.003 \mathrm{mg} \mathrm{l}^{-1}$ and any peaks in $\mathrm{NH}_{3}$ were still well below toxic levels (recorded peaks $<0.1 \mathrm{mg} \mathrm{l}^{-1}$ ). Liquid zeolite $(25 \mathrm{ml})$ was used during the international leg of the transport chain to regulate ammonia concentrations. The ammonia concentrations in the present study $\left(0.005 \mathrm{mg} \mathrm{l}^{-1}\right)$ are in line with the zeolite treatment in a study by Bower and Turner (1982) $\left(0.007 \mathrm{mg} \mathrm{l}^{-1}\right)$ who compared $\mathrm{NH}_{3}$ levels in bags containing 0-20 g zeolites following a $24 \mathrm{~h}$ simulated transport with 10 or 20 goldfish (C. auratus) in $500 \mathrm{ml}$ water. Elevated $\mathrm{NO}_{3}{ }^{-}$levels $\left(>50 \mathrm{mg} \mathrm{l}^{-1}\right)$ can lead to poor growth, lethargy, 
anorexia and opportunistic infections (Roberts and Palmeiro, 2008). The levels recorded in this study were on average $<17 \mathrm{ml} \mathrm{l}^{-1}$, well below this threshold.

The present study measured a range of chemical elements including $\mathrm{NO}_{3}{ }^{-}, \mathrm{Cl}^{-}, \mathrm{Ca}^{2+}$ and trace metals. The results showed that the levels of some chemical elements in the water fluctuated between species (potassium and magnesium), between stages of transport $\left(\mathrm{PO}_{4}{ }^{3-}\right.$ and sodium) or between both species and stages $\left(\mathrm{NO}_{3}{ }^{-}, \mathrm{SO}_{4}{ }^{2-}, \mathrm{Cl}^{-}\right.$and $\left.\mathrm{Ca}^{2+}\right)$. Similar data were collected in a previous study which compared ion levels in water between multiple water sources of a commercial supply chain in Nile tilapia (Oreochromis niloticu) (Colt et al., 2011). This fluctuation in chemical elements highlights that ornamental fishes can be exposed to different water qualities through the supply chain. Fluctuation in water chemistry between times points is likely due to daily or geographical fluctuations but further research is needed. It is unclear why water chemistry was different between species within a time point as they were always exposed to water from the same source. Differences in feed composition or fish physiology might result in the observed fluctuation however this requires further investigation. In this study, the trace metals measured were below the detection limit for the majority of samples; the few samples that did contain detectable levels were within levels considered safe for freshwater fishes (Poléo, 1995; Roberts and Palmeiro, 2008). Overall whilst water quality was appropriate for each species at all stages of transport, fishes experienced significant changes in water chemistry between different stages; the effect of this fluctuation in water quality demands further examination.

The water was tested for the presence of common bacterial pathogens and a free-living amoeba which can harbour pathogens. None of the water samples collected were pathogen-free with E. coli, F. columnare and $V$. anguillarum pathogens being found in over $90 \%$ of the samples. The number of samples which tested positive for Aeromonas spp., Pseudomonas spp. and Mycobacterium spp. was significantly lower on day 5 at the retail stores than on arrival at the wholesaler. However, there was no clear pattern in the presence/absence of the other pathogens across the transport chain indicating that the microbial control measures taken by the wholesaler (tetracycline) and the stores (UV light filter) reduce some of the pathogenic microbial load in the supply chain. Rose et al. (2013) found bacteria isolated from 15 genera in imported ornamental fishes and associated water, however their 
detection of common fish pathogens was low for some genera (e.g. Vibrio spp.). Other studies, such as Trust and Bartlett (1974) and Zanoni et al. (2008), also detected pathogenic genera (e.g. Vibrio spp. and Mycobacterium spp.) in ornamental fishes or their water that were either recently imported or sold in retail stores. The difference in detected genera between studies shows how variable the bacterial load can be in supply chains. Many importers receive fishes from several farms and continents; while at the importer, cross-contamination can occur between species from different origins via husbandry practices resulting in the introduction of potential pathogens in non-contaminated water. Further research is needed to better understand the prevalence and transfer of pathogens into the ornamental fish trade.

In the present study, only microbial presence in the water was tested. Although no disease outbreaks were recorded during this study, it was not possible to determine whether all the fish were disease-free. In oranda, eye colour was significantly darker in the presence of Mycobacterium spp., however, there were no other typical signs of mycobacteriosis seen (scale loss, anorexia, lethargy, skin ulcers, fin and tail rot) (Alapide-Tendencia and Peña, 2002; Austin and Austin, 2012; Smith, 1997). Over 150 species make up the genus Mycobacterium spp. and at least 20 species have been associated with fish, however, it is not always clear if species are the causative agent of mycobacteriosis as multiple species have been detected in diseased fish (Keller et al., 2018). As the primers used to test for Mycobacterium in the present study were genus specific and not speciesspecific, it cannot be determined if the fish were at risk of mycobacteriosis. Mycobacterium spp. can cause both depigmentation or hyperpigmentation of fishes (Smith, 1997) but the author does not specify which species causes this colour change. The identity of species causing and whether colouration of the eye is affected by Mycobacterium spp. in the same way as body colour is unknown. Eye colour in fishes has also been reported to darken with stress including social stress (Suter and Huntingford, 2002; Freitas et al., 2014; Volpato et al., 2003). Further research is needed to better understand causes and correlates of eye colour changes in fishes. weakened immune system (Scholz, 1999; Yanong, 2010). It is therefore important to recognise signs 
of stress and poor welfare in ornamental fishes during commercial transport which may indicate increased susceptibility to waterborne pathogens. Mortality levels in our study were low for all three species and were not affected by transport stage. Other studies suggest that mortality is likely to be higher during recovery periods than immediately post-transport (Ali et al., 1989; Kilgore et al., 2009) so it may be of benefit in the future to monitor mortality at retail stores over a longer time period. Of course, retail stores are usually not the end-point of the journey of an ornamental fish and understanding mortality effects may need to include the journey from retailer to owner and recovery in home aquaria.

Out of the recorded stress measures, behaviour was found to change the most between stages of transport. Due to the small size of neon tetra, observing individual's behaviour was not possible, therefore, studying behaviour of this species in a commercial setting is challenging. Oranda had low levels of activity at most stages of the transport chain although a small increase in erratic swimming was seen during recovery at the stores. This increase in erratic swimming was small, however and may not represent a biologically relevant change. In contrast, variatus platy displayed the greatest changes in behaviours across the transport chain. The high levels of erratic swimming at the wholesaler may be associated with the activity of wholesaler staff, which were observed to disturb the fish. Housing variatus platy in tanks in a quieter area of the wholesaler facilities could therefore help reduce stress for this species. At the retail stores, erratic swimming was much lower in variatus platy compared to at the wholesalers which could be due to differences in housing conditions (e.g. stocking density, lighting, enrichment). In contrast, biting increased during recovery at the stores. Biting occurs in particular during the establishment of hierarchies and can result in stress and injury (Noble et al., 2012; Pitcher, 1986). This increase in biting behaviour in variatus platy at the retail stores was accompanied by a decrease in freezing behaviour, likely as a result of the fish avoiding bites and aggression from conspecifics (Braddock, 1945; Scott and Currie, 1980). The decrease in erratic swimming behaviour from the wholesaler to the store may indicate a reduction in stress following transport. It is possible that platys were still experiencing transport-related stress during recovery at the wholesaler. As this stress started to reduce during recovery at the stores, establishment of 
hierarchies may have been initiated indicated by the progressive increase in biting behaviour

508 (Braddock, 1945; Scott and Currie, 1980; Noble et al., 2012). Continued aggression beyond the initial 509 hierarchy establishment could be detrimental causing chronic stress in some individuals (Sloman and

510 Armstrong, 2002), therefore practices promoting more rapid and peaceful hierarchy establishment

511 would improve the welfare of ornamental fish following transport.

512 Behavioural changes were found to be species-specific, therefore study species must be selected 513 with this in mind, and a species-specific ethogram is needed when using changes in behaviour as an indicator of stress. Our multivariate analyses indicate that some fluctuation in water chemistry can influence stress-associated behaviours. Studies focusing on the effect of low water quality in ornamental fish welfare tend to focus on mortality or physiological response (Gonzalez et al., 1998; Brinn et al., 2012), however, here we show that water quality can also influence the behaviour of fishes. Future studies on the response of fishes to water quality should record behavioural changes as this may provide additional information (Abreu et al., 2014; Brinn et al., 2012). Other stress measures tested in this study did not vary between transport stages. Although large concentrations of waterborne cortisol were measured in the water on arrival at the wholesaler and arrival at the stores, when adjusted to account for excretion per fish per hour, the levels between the two data collection points were not significantly different. Eye darkening was not found to vary across the transport chain however, eye colour measurement was limited by the use of methylene blue and the variability in lighting conditions at the wholesaler. Eye darkening as a stress-indicator in a brighter, more controlled environment might be more reliable.

Conclusion

This study is the first to record water quality and ornamental fish welfare through a commercial chain. This study emphasises the complexity of studying ornamental fish welfare during commercial transport and that exposure to changes in water chemistry, within acceptable water quality parameters,

531 should also be considered in studies of fish transport as water quality was found to influence the

532 recorded behaviours. The study of animals within commercial transport chains often requires non- 
invasive methods; here we find that monitoring behaviour is a useful tool but one that is speciesspecific.

\section{Acknowledgements}

The authors would like to thank the management and staff at the wholesaler and retail stores for their assistance in collecting data. We would like to thank the laboratory technicians at the University of the West of Scotland for their support and advice with sample processing.

\section{References}

Abreu, J.S., Brinn, R.P., Gomes, L.C., McComb, D.M., Baldisserotto, B., Zaiden, S.F., Urbinati, E.C., Marcon, J.L., 2014. Effect of beta 1, 3 glucan in stress responses of the pencilfish (Nannostomus trifasciatus) during transport within the rio Negro basin. Neotropical Ichthyology 12, 623-628. https://doi.org/10.1590/1982-0224-20130121

Alapide-Tendencia, E. V, de la Peña, L.D., 2002. Bacterial diseases, in: Lio-Po, D., Lavilla, C.R., Cruz-Lacierda, E.R. (Eds.), Health Management in aquaculture. Aquaculture Department, Southeast Asian Fisheries Development Center, Tigbauan, Iloilo, Philippines, pp. 25-41.

Ali, A.B., Kamalden, M.I., Abas, A., 1989. Preliminary study on mortality of catfish (Clarias macrocephalus) fry transported in plastic bags. Pertanika 12, 335-340.

Alvarenga, C.M.D., Volpato, G.L., 1995. Agonistic profile and metabolism in alevins of the Nile tilapia. Physiology and Behavior 57, 75-80. https://doi.org/10.1016/0031-9384(94)00206-K

Amal, M.N., Zamri-Saad, M., 2011. Streptococcosis in Tilapia (Oreochromis niloticus): a review. Pertanika Journal of Tropical Agricultural Science 34, 195-206.

Anderson, M.J., Gorley, R.N., Clarke, K.R., 2016. PERMANOVA+ for PRIMER: guide to software and statistical methods. PRIMER-E Ltd, Lutton, UK. http://updates.primere.com/primer7/manuals/PERMANOVA+_manual.pdf

Austin, B., Allen-Austin, D., 1985. A review: bacterial pathogens of fish. Journal of Applied 
Austin, B., Austin, D.A. (Eds.), 2012. Bacterial Fish Pathogens, 4th ed, Springer, Heidelberg, Germany. https://doi.org/10.1007/978-1-4020-6069-4 2

Azambuja, C.R., Mattiazzi, J., Riffel, A.P.K., Finamor, I.A., Garcia, L. de O., Heldwein, C.G., Heinzmann, B.M., Baldisserotto, B., Pavanato, M.A., Llesuy, S.F., 2011. Effect of the essential oil of Lippia alba on oxidative stress parameters in silver catfish (Rhamdia quelen) subjected to transport. Aquaculture 319, 156-161. https://doi.org/10.1016/j.aquaculture.2011.06.002

Backström, T., Heynen, M., Brännäs, E., Nilsson, J., Winberg, S., Magnhagen, C., 2015. Social stress effects on pigmentation and monoamines in Arctic charr. Behavioural Brain Research 291, $103-$ 107. https://doi.org/10.1016/j.bbr.2015.05.011

Baldisserotto, B., Romero, J.M.M., Kapoor, B.G. (Eds.), 2007. Fish Osmoregulation. Science Publishers, Enfield, USA. https://doi.org/10.1086/598309

Baldisserotto, B., Brinn, R.P., R. Brandão, F., C. Gomes, L., Abreu, J.S., Mccomb, D.M., Marcon, J.L., 2014. Ion flux and cortisol responses of cardinal tetra, Paracheirodon axelrodi (Schultz, 1956), to additives (tetracycline, tetracycline + salt or Amquel ${ }^{\circledR}$ ) used during transportation: contributions to amazonian ornamental fish trade. Journal of Applied Ichthyology 30, 86-92. https://doi.org/10.1111/jai.12282

Barreto, R.E., Volpato, G.L., 2004. Caution for using ventilatory frequency as an indicator of stress in fish. Behavioural Processes 66, 43-51. https://doi.org/10.1016/j.beproc.2004.01.001

Bates, D., Maechler, M., Bolker, B., Walker, S., 2015. Fitting linear mixed-effects models using lme4. Journal of Statistical Software 67, 1-48. https://doi.org/10.18637/jss.v067.i01

Bolker, B.M., Brooks, M.E., Clark, C.J., Geange, S.W., Poulsen, J.R., Stevens, M.H.H., White, J.S.S., 2009. Generalized linear mixed models: a practical guide for ecology and evolution. Trends in Ecology and Evolution 24, 127-135. https://doi.org/10.1016/j.tree.2008.10.008

Bower, C.E., Holm-Hansen, T., 1980. A Salicylate-hypochlorite method for determining ammonia in 
seawater. Canadian Journal of Fisheries and Aquatic Sciences 37, 794-798.

Bower, C.E., Turner, D.T., 1982. Ammonia removal by clinoptilolite in the transport of ornamental freshwater fishes. Progressive Fish-Culturist 44, 19-23. https://doi.org/10.1577/1548-

Braddock, J.C., 1945. Some aspects of the dominance-subordination relationship in the fish Platypoecilus maculatus. Physiological Zoology 18, 176-195. https://doi.org/10.1086/physzool.18.2.30151863

Braithwaite, V.A., Ebbesson, L.O.E., 2014. Pain and stress responses in farmed fish. Revue Scientifique et Technique-Office International des Epizooties 33, 245-253.

Braithwaite, V.A., Salvanes, A.G. V., 2005. Environmental variability in the early rearing environment generates behaviourally flexible cod: implications for rehabilitating wild populations. Proceedings of the Royal Society B: Biological Sciences 272, 1107-1113. https://doi.org/10.1098/rspb.2005.3062

Brinn, R.P., Marcon, J.L., McComb, D.M., Gomes, L.C., Abreu, J.S., Baldisseroto, B., 2012. Stress responses of the endemic freshwater cururu stingray (Potamotrygon cf. histrix) during transportation in the Amazon region of the Rio Negro. Comparative Biochemistry and Physiology - A Molecular and Integrative Physiology 162, 139-145.

California Water Boards Agency, 2011. Formulas used to derive un-ionized ammonia fractions and USEPA ammonia criteria. https://www.waterboards.ca.gov/waterrights/water_issues/programs/bay_delta/docs/cmnt081712 
Cecil, T.R., 1999. Husbandry and husbandry-related diseases of ornamental fish. The Veterinary Clinics of North America: Exotic Animal Practice 2, 1-18. https://doi.org/10.1016/S10949194(17)30137-8

Citarasu, T., Dhas, A.K., Velmurugan, S., Thanga Viji, V., Kumaran, T., Babu, M.M., Selvaraj, T., 2011. Isolation of Aeromonas hydrophila from infected ornamental fish hatchery during massive disease outbreak. International Journal of Current Research 2, 37-41.

Clarke, K.R., Gorley, R.N., 2015. PRIMER 7. PRIMER-E Ltd, Plymouth, UK. http://updates.primere.com/primer7/manuals/User manual v7a.pdf

Cohen, F.P.A., Valenti, W.C., Calado, R., 2013. Traceability issues in the trade of marine ornamental species. Reviews in Fisheries Science 21, 98-111. https://doi.org/10.1080/10641262.2012.760522

Cole, B., Tamaru, C.S., Bailey, R., Brown, C., Ako, H., 1999. Shipping practices in the ornamental fish industry. Waimanalo, HI: Center for Tropical and Subtropical Aquaculture. https://articles.extension.org/mediawiki/files/8/86/Shipping_Practices_in_the_Ornamental_Fish_ $\underline{\text { Industry.pdf }}$

Colt, J., Momoda, T., Chitwood, R., Fornshell, G., Schreck, C., 2011. Water quality in tilapia transport: from the farm to the retail store. North American Journal of Aquaculture 73, 426-434. https://doi.org/10.1080/15222055.2011.629946

Conte, F.S., 2004. Stress and the welfare of cultured fish. Applied Animal Behaviour Science 86, 205-223. https://doi.org/10.1016/j.applanim.2004.02.003

Correia, J.P.S., Graça, J.T.C., Hirofumi, M., Kube, N., 2011. Long-term transportation, by road and air, of chub mackerel (Scomber japonicus) and Atlantic bonito (Sarda sarda). Zoo Biology 30, 459-472. https://doi.org/10.1002/zoo.20342

Crosby, T.C., Hill, J.E., Martinez, C. V, Watson, C.A., Pouder, D.B., Roy, P.E., 2005. Preparation of 

ornamental fish for shipping. University of Florida Institute of Food and Agricultural Sciences Extension Publication FA, 120, 1-9.

Cruz, E.M.V., Tauli, M.P., 2015. Eye color pattern during isolation indicates stress-coping style in Nile tilapia Oreochromis niloticus L. International Journal of Scientific Research in Knowledge $3,181-186$.

Decostere, A., Haesebrouck, F., Van Driessche, E., Charlier, G., Ducatelle, R., 1999. Characterization of the adhesion of Flavobacterium columnare (Flexibacter columnaris) to gill tissue. Journal of Fish Diseases 22, 465-474. https://doi.org/10.1046/j.1365-2761.1999.00198.x

Defra: Department for Environment, Food and Rural Affairs, 2011. Welfare of animals during transport - Council regulation (EC) No 1/2005 on the protection of animals during transport and related operations. The welfare of animals (transport) (England) order 2006 and parallel national legislation in Scotland, Wales and Northern Ireland. http://adlib.everysite.co.uk/resources/000/264/374/fitness2a.pdf

Delgado De Carvalho, C., Marocco Corneta, C., Sanches Uieda, V., 2007. Schooling behavior of Mugil curema (Perciformes : Mugilidae ) in an estuary in southeastern Brazil. Neotropical Ichthyology 5, 81-83.

Deng, Z., Guensch, G.R., McKinstry, C.A., Mueller, R.P., Dauble, D.D., Richmond, M.C., 2005. Evaluation of fish-injury mechanisms during exposure to turbulent shear flow. Canadian Journal of Fisheries and Aquatic Sciences 62, 1513-1522. https://doi.org/10.1139/f05-091

Ellis, T., James, J.D., Stewart, C., Scott, A.P., 2004. A non-invasive stress assay based upon measurement of free cortisol released into the water by rainbow trout. Journal of Fish Biology 65, 1233-1252. https://doi.org/10.1111/j.1095-8649.2004.00499.x

European Union, 2005. Council Regulation (EC) No 1/2005 of 22 December 2004 on the protection of animals during transport and related operations and amending Directives 64/432/EEC and 93/119/EC and Regulation (EC) No 1255/97, Official Journal of the European Union. 
Evans, D.H., 2008. Teleost fish osmoregulation: what have we learned since August Krogh, Homer Smith, and Ancel Keys. American Journal of Physiology-Regulatory, Integrative and Comparative Physiology. 295, 704-713. https://doi.org/10.1152/ajpregu.90337.2008

Ferreira, P.D.M.F., Rocha, J.S., Gomes, J.R., Caldas, D.W., Martins, M.T.S., Oliveira, J.M., Salaro, A.L., Zuanon, J.A.S., 2017. Curcuma longa supplementation in the diet of Astyanax aff. bimaculatus in preparation for transport. Aquaculture Research 48, 4524-4532. https://doi.org/10.1111/are.13277

Fox, J., Weisberg, S., 2011. An R Companion to Applied Regression, second. ed. Sage Publicatoins, Thousand Oaks, CA.

Freitas, R.H.A., Negrão, C.A., Felício, A.K.C., Volpato, G.L., 2014. Eye darkening as a reliable, easy and inexpensive indicator of stress in fish. Zoology 117, 179-184. https://doi.org/10.1016/j.zool.2013.09.005

Friard, O., Gamba, M., 2016. BORIS: a free, versatile open-source event-logging software for video/audio coding and live observations. Methods in Ecology and Evolution 7, 1325-1330. https://doi.org/10.1111/2041-210X.12584

Gauthier, D.T., Rhodes, M.W., 2009. Mycobacteriosis in fishes: a review. Veterinary Journal 180, 33-47. https://doi.org/10.1016/j.tvj1.2008.05.012

Harmon, T.S., 2009. Methods for reducing stressors and maintaining water quality associated with live fish transport in tanks: a review of the basics. Reviews in Aquaculture 1, 58-66. https://doi.org/10.1111/j.1753-5131.2008.01003.x

Håstein, T., Scarfe, A.D., Lund, V.L., 2005. Science-based assessment of welfare: aquatic animals. Revue Scientifique et Technique-Office International des Epizooties 24, 529-547.

Hernández, E., Figueroa, J., Iregui, C., 2009. Streptococcosis on a red tilapia, Oreochromis sp., farm: a case study. Journal of Fish Diseases 32, 247-252. https://doi.org/10.1111/j.1365$\underline{2761.2008 .00981 . x}$ 
Huntingford, F.A., Adams, C., Braithwaite, V.A., Kadri, S., Pottinger, T.G., Sandøe, P., Turnbull, J.., 2006. Current issues in fish welfare. Journal of Fish Biology 68, 332-372. https://doi.org/10.1111/j.1095-8649.2005.01046.x

Inoue, L.A.K.A., Afonso, L.O.B., Iwama, G.K., Moraes, G., 2005. Effects of clove oil on the stress response of matrinxã (Brycon cephalus) subjected to transport. Acta Amazonica 35, 289-295.

Kalueff, A. V., Gebhardt, M., Stewart, A.M., Cachat, J.M., Brimmer, M., Chawla, J.S., Craddock, C., Kyzar, E.J., Roth, A., Landsman, S., Gaikwad, S., Robinson, K., Baatrup, E., Tierney, K., Shamchuk, A., Norton, W., Miller, N., Nicolson, T., Braubach, O., Gilman, C.P., Pittman, J., Rosemberg, D.B., Gerlai, R., Echevarria, D., Lamb, E., Neuhauss, S.C.F., Weng, W., BallyCuif, L., Schneider, H., Zebrafish Neuroscience Research Consortium, 2013. Towards a comprehensive catalog of zebrafish behavior 1.0 and beyond. Zebrafish 10, 70-86. https://doi.org/10.1089/zeb.2012.0861

Keller, C., Wenker, C., Jermann, T., Hirschi, R., Schildger, B., Meier, R., Schmidt-Posthaus, H., 2018. Piscine mycobacteriosis - involvement of bacterial species and reflection in pathology. Schweiz Arch Tierheilkd 160, 385-393. https://doi.org/10.17236/sat00165

Kilgore, K.H., Hill, J.E., Powell, J.F.F., Watson, C.A., Yanong, R.P.E., 2009. Investigational use of metomidate hydrochloride as a shipping additive for two ornamental fishes. Journal of Aquatic Animal Health 21, 133-139. https://doi.org/10.1577/H08-030.1

Koolhaas, J.M., Korte, S.M., De Boer, S.F., Van Der Vegt, B.J., Van Reenen, C.G., Hopster, H., De Jong, I.C., Ruis, M.A.W., Blokhuis, H.J., 1999. Coping styles in animals: current status in behavior and stress- physiology. Neuroscience and Biobehavioral Reviews 23, 925-935. https://doi.org/10.1016/S0149-7634(99)00026-3

Korner-Nievergelt, F., Roth, T., von Felten, S., Guelat, J., Almasi, B., Korner-Nievergelt, P., 2015. blmeco: data files and functions accompanying the book, in: Bayesian Data Analysis in Ecology Using R, BUGS and Stan. Elsevier, New York, USA. 
Kramer, D.L., 1987. Dissolved oxygen and fish behavior. Environmental Biology of Fishes 18, 8192. https://doi.org/10.1007/BF00002597

Leal, M.C., Vaz, M.C.M., Puga, J., Rocha, R.J.M., Brown, C., Rosa, R., Calado, R., 2015. Marine ornamental fish imports in the European Union: an economic perspective. Fish and Fisheries 17, 459-468. https://doi.org/10.1111/faf.12120

Lenth, R., Singmann, H., Love, J., Buerkner, P., Herve, M., 2019. emmeans: estimated marginal means, aka least-squares means. R package. https://cran.rproject.org/web/packages/lsmeans/lsmeans.pdf

Lim, L.C., Dhert, P., Sorgeloos, P., 2003. Recent developments in the application of live feeds in the freshwater ornamental fish culture. Aquaculture 227, 319-331. https://doi.org/10.1016/S0044$\underline{8486(03) 00512-X}$

Magurran, A.E., Pitcher, T.J., 1983. Foraging, timidity and shoal size in minnows and goldfish. Behavioral Ecology and Sociobiology 12, 147-152. https://doi.org/10.1007/BF00343206

Martins, C.I.M., Galhardo, L., Noble, C., Damsgard, B., Spedicato, M.T., Zupa, W., Beauchaud, M., Kulczykowska, E., Massabuau, J.C., Carter, T., Planellas, S.R., Kristiansen, T., 2012. Behavioural indicators of welfare in farmed fish. Fish Physiology and Biochemistry 38, 17-41. https://doi.org/10.1007/s10695-011-9518-8

Mikheev, V.N., Metcalfe, N.B., Huntingford, F.A., Thorpe, J.E., 1994. Size-related differences in behaviour and spatial distribution of juvenile Atlantic salmon in a novel environment. Journal of Fish Biology https://doi.org/10.1111/j.1095-8649.1994.tb01320.x

Monticini, P., 2010. The Ornamental Fish Trade - Production and commerce of ornamental fish: technical-managerial and legislative aspects, Food and Agriculture Organization of the United Nations, GLOBEFISH Research Programme. Rome, Italy. http://www.fao.org/3/a-bb206e.pdf

Murphy, K.M., Lewbart, G.A., 1995. Aquarium fish dermatologic diseases. Seminars in Avian and Exotic Pet Medicine 4, 220-233. https://doi.org/10.1016/S1055-937X(05)80019-2 
Neitzel, D.A., Dauble, D.D., Cada, G.F., Richmond, M.C., Guensch, G.R., Mueller, R.R., Abernethy, C.S., Amidan, B., 2004. Survival estimates for juvenile fish subjected to a laboratory-generated shear environment. Transactions of the American Fisheries Society 133, 447-454. https://doi.org/Doi 10.1577/02-021

Noble, C., Jones, H.A.C., Damsgård, B., Flood, M.J., Midling, K.O., Roque, A., Sæther, B.S., Cottee, S.Y., 2012. Injuries and deformities in fish: their potential impacts upon aquacultural production and welfare. Fish Physiology and Biochemistry 38, 61-83. https://doi.org/10.1007/s10695-0119557-1

Oliveira, S.R., Souza, R.T.Y.B., Nunes, E.S.S., Carvalho, C.S.M., Menezes, G.C., Marcon, J.L., Roubach, R., Akifumi Ono, E., Affonso, E.G., 2008. Tolerance to temperature, pH, ammonia and nitrite in cardinal tetra, Paracheirodon axelrodi, an amazonian ornamental fish. Acta Amazonica 38, 773-780.

Olivier, K., 2003. World trade in ornamental species, in: James, C.C., Brown, C.L. (Eds.), Marine Ornamental Species: Collection, Culture and Conservation. Iowa State Press, Ames, USA, pp. 49-64. https://doi.org/10.1002/9780470752722.ch4

Pinheiro, J., Bates, D., DebRoy, S., Sarkar, D., R Core Team, 2018. nlme: linear and nonlinear mixed effects models. https://cran.r-project.org/web/packages/nlme/nlme.pdf

Pitcher, T.J. (Ed.), 1986. The Behaviour of Teleost Fishes, Springer Science \& Business Media. Croom Helm, London, UK. https://doi.org/10.1007/978-1-4684-8261-4 5

Poléo, A.B.S., 1995. Aluminium polymerization - a mechanism of acute toxicity of aqueous aluminium to fish. Aquatic Toxicology 31, 347-356. https://doi.org/10.1016/0166445X(94)00083-3

Portz, D.E., Woodley, C.M., Cech, J.J., 2006. Stress-associated impacts of short-term holding on fishes. Reviews in Fish Biology and Fisheries 16, 125-170. https://doi.org/10.1007/s11160-006$\underline{9012-\mathrm{Z}}$ 
Prearo, M., Zanoni, R.G., Campo Dall’Orto, B., Pavoletti, E., Florio, D., Penati, V., Ghittino, C., 2004. Mycobacterioses: emerging pathologies in aquarium fish. Veterinary Research Communications 28, 315-317. https://doi.org/10.1023/B:VERC.0000045435.19522.af

R Core Team, 2018. R: a language and environment for statistical computing. https://www.rproject.org/

Ramírez-duarte, W.F., Pineda-quiroga, C., Rueda, N.M., 2013. Evaluation of the use of sodium chloride, eugenol, and zeolite in confinement of Ancistrus triradiatus. Orinoquia 17, 84-95.

Randall, D.J., Tsui, T.K.N., 2002. Ammonia toxicity in fish. Marine Pollution Bulletin 45, 17-23. https://doi.org/10.1016/S0025-326X(02)00227-8

Roberts, H., Palmeiro, B.S., 2008. Toxicology of aquarium fish. Veterinary Clinics of North America: Exotic Animal Practice 11, 359-374. https://doi.org/10.1016/j.cvex.2007.12.005

Roberts, H.E., Palmeiro, B., Weber, E.S., 2009. Bacterial and parasitic diseases of pet fish. Veterinary Clinics of North America: Exotic Animal Practice 12, 609-638. https://doi.org/10.1016/j.cvex.2009.06.010

Rodrigues, N., Correia, J.A., Pinho, U., Graç, J.E., Rodrigues, F., Hirofumi, M., 2013. Notes on the husbandry and long-term transportation of bull ray (Pteromylaeus bovinus) and dolphinfish (Coryphaena hippurus and Coryphaena equiselis). Zoo Biology 32, 222-229. https://doi.org/10.1002/zoo.21048

Rose, S., Hill, R., Bermudez, L.E., Miller-Morgan, T., 2013. Imported ornamental fish are colonized with antibiotic-resistant bacteria. Journal of Fish Diseases 36, 533-542. https://doi.org/10.1111/jfd.12044

Ruane, N.M., Komen, H., 2003. Measuring cortisol in the water as an indicator of stress caused by increased loading density in common carp (Cyprinus carpio). Aquaculture 218, 685-693. https://doi.org/10.1016/S0044-8486(02)00422-2

Salbego, J., Becker, A.G., Parodi, T. V., Zeppenfeld, C.C., Gonçalves, J.F., Loro, V.L., Morsch, 
V.M.M., Schetinger, M.R.C., Maldaner, G., Morel, A.F., Baldisserotto, B., 2015. Methanolic extract of Condalia buxifolia added to transport water alters biochemical parameters of the silver catfish Rhamdia quelen. Aquaculture 437, 46-50. https://doi.org/10.1016/j.aquaculture.2014.11.022

Sampaio, F.D.F., Freire, C.A., 2016. An overview of stress physiology of fish transport: changes in water quality as a function of transport duration. Fish and Fisheries 17, 1055-1072. https://doi.org/10.1111/faf.12158

Saxby, A., Adams, L., Snellgrove, D., Wilson, R.W., Sloman, K.A., 2010. The effect of group size on the behaviour and welfare of four fish species commonly kept in home aquaria. Applied Animal Behaviour Science 125, 195-205. https://doi.org/10.1016/j.applanim.2010.04.008

Scholz, T., 1999. Parasites in cultured and feral fish. Veterinary Parasitology 84, 317-335. https://doi.org/10.1016/S0304-4017(99)00039-4

Schreck, C.B., Olla, B.L., Davis, M.W., 1997. Behavioral responses to stress, in: Iwama, G.K., Pickering, A.D., Sumpter, J.P., Schreck., C.B. (Eds.), Fish Stress and Health in Aquaculture. Cambridge University Press, Cambridge, UK, pp. 145-170.

Scott, D.B.C., Currie, C.E., 1980. Social hierarchy in relation to adrenocortical activity in Xiphophorus helleri Heckel. Journal of Fish Biology 16, 265-277. https://doi.org/10.1111/j.1095-8649.1980.tb03704.x

Shuhaimi-Othman, M., Yakub, N., Ramle, N.A., Abas, A., 2015. Comparative toxicity of eight metals on freshwater fish. Toxicology and Industrial Health 31, 773-782. https://doi.org/10.1177/0748233712472519

Silva, R.E., Morais, H.A., Rodrigues, N. V, Reis, T., Correia, J.P., 2015. Optimising sealed transports of small ornamental fish. Journal of Zoo and Aquarium Research 3, 141-150.

Sloman, K. A. and Armstrong, J. D., 2002. Physiological effects of dominance hierarchies: laboratory artefacts or natural phenomena? Journal of Fish Biology 61, 1-23. 
Smith, S.A., 1997. Mycobacterial infections in pet fish. Seminars in Avian and Exotic Pet Medicine 6,

$$
\text { 40-45. https://doi.org/10.1016/s1055-937x(97)80040-0 }
$$

Spry, D.J., Wiener, J.G., 1991. Metal bioavailability and toxicity to fish in low-alkalinity lakes: a critical review. Environmental Pollution 71, 243-304. https://doi.org/10.1016/02697491(91)90034-T

Suter, H., Huntingford, F.A., 2002. Eye colour in juvenile Atlantic salmon: effects of social status, aggression and foraging success. Jouranl of Fish Biology 61, 606-614. https://doi.org/10.1006/jfbi.2002.2084

Teo, L.H., Chen, T.W., Lee, B.H., 1989. Packaging of the guppy, Poecilia reticuluta, for air transport in a closed system. Aquaculture 78, 321-332. https://doi.org/10.1016/0044-8486(89)90109-9

Thune, R.L., Stanley, L.A., Cooper, R.K., 1993. Pathogenesis of gram-negative bacterial infections in warmwater fish. Annual Review of Fish Diseases 3, 37-68. https://doi.org/10.1016/0959$\underline{8030(93) 90028-\mathrm{A}}$

Trust, T.J., Bartlett, K.H., 1974. Occurrence of potential pathogens in water containing ornamental fishes. Applied Microbiology 28, 35-40.

United Nations, 2019. United Nations comtrade data. https://comtrade.un.org/

US EPA (United States Environmental Protection Agency) 1984. Ambient water quality criteria for ammonia—1984. National Technical Information Service, Springfield, VA.

Venables, W.N., Ripley, B.D., 2002. Modern applied statistics with S. Fourth Edition. Springer, New York, USA.

Volpato, G.L., Luchiari, A.C., Duarte, C.R.A., Barreto, R.E., Ramanzini, G.C., 2003. Eye color as an indicator of social rank in the fish Nile tilapia. Brazilian Journal of Medical and Biological Research 36, 1659-1663. https://doi.org/10.1590/S0100-879X2003001200007

Weber, E.S., 2011. Fish analgesia: pain, stress, fear aversion, or nociception? Veterinary Clinics of 
Whipps, C.M., Lieggi, C., Wagner, R., 2012. Mycobacteriosis in zebrafish colonies. Institute for Laboratory Animal Research Journal 53, 95-105. https://doi.org/10.1093/ilar.53.2.95

White, L.J., Thomson, J.S., Pounder, K.C., Coleman, R.C., Sneddon, L.U., 2017. The impact of social context on behaviour and the recovery from welfare challenges in zebrafish, Danio rerio. Animal Behaviour 132, 189-199. https://doi.org/10.1016/j.anbehav.2017.08.017

Wickham, H., 2016. ggplot2: elegant graphics for data analysis. Second edition, Springer-Verlag New York. https://doi.org/10.1007/978-0-387-98141-3

Yanong, R.P.E., 2010. Use of antibiotics in ornamental fish aquaculture. University of Florida Institute of Food and Agricultural Sciences Extension Publication Cir. 84, 1-8 https://doi.org/186 Mycobacterium spp. in ornamental fish in Italy. Journal of Fish Diseases 31, 433-441. https://doi.org/10.1111/j.1365-2761.2008.00924.x

Zanuzzo, F.S., Sabioni, R.E., Montoya, N.F., Favero, G., Urbinati, E.C., 2017. Aloe vera enhances the innate immune response of pacu (Piaractus mesopotamicus) after transport stress and combined heat killed Aeromonas hydrophila infection. Fish and Shellfish Immunology 65, 198-205. https://doi.org/10.1016/j.fsi.2017.04.013

\section{Declaration of interest}

850 One author was employed by Pets at Home, he was not involved in data collection or analysis but was involved in the experimental design and provided feedback on earlier drafts of the manuscript. 


\section{Figure Legends}

855 Figure $1(\mathrm{~A})$ DO levels $(\%)(\mathrm{n}=10)$ and $(\mathrm{B})$ temperature $\left({ }^{\circ} \mathrm{C}\right)(\mathrm{n}=10)$ through the transport stages (WS $\mathrm{A}=$ wholesaler arrival, WS $1=$ wholesaler recovery day 1 , WS $2=$ wholesaler recovery day 2 , WS $5=$ wholesaler recovery day $5, \mathrm{P}=$ packing for transport to stores, Store $\mathrm{A}=$ store arrival, Store $1=$ store recovery day 1 , Store $2=$ store recovery day 2 , Store $5=$ store recovery day 5 ) showing the mean (diamond), median, upper and lower 25th percentile, and outliers. Letters indicate differences between species within a specific time point where boxes sharing a letter are not significantly different. Asterisks indicate significant differences within a species between different transport stages (posthoc Tukey, $\mathrm{P}<0.05)$.

863 Figure 2: (A) $\mathrm{pH}(\mathrm{n}=10)$ through the transport stages (WS A=wholesaler arrival, WS 1= wholesaler recovery day 1 , WS $2=$ wholesaler recovery day 2 , WS $5=$ wholesaler recovery day $5, \mathrm{P}=$ packing for transport to stores, Store A= store arrival, Store $1=$ store recovery day 1 , Store $2=$ store recovery day 2 , Store $5=$ store recovery day 5 ) showing the mean (diamond), median, upper and lower 25 th percentile, and outliers. Asterisks indicate significant differences within a species between different transport stages. (B) Kh $\left({ }^{\circ} \mathrm{dKh}\right.$ ) showing mean and standard error (there was no significant difference between species (see text) so the data were combined across species, $n=30$ ). Letters indicate differences between time points where boxes sharing a letter are not significantly different (post-hoc Tukey, $\mathrm{P}<0.05)$.

Figure 3: (A) TAN (ppm) $(\mathrm{n}=10)$ and $(\mathrm{B}) \mathrm{NH}_{3}(\mathrm{n}=10)$ through the transport stages (WS A=wholesaler arrival, WS $1=$ wholesaler recovery day 1 , WS $2=$ wholesaler recovery day 2 , WS $5=$ wholesaler recovery day $5, \mathrm{P}=$ packing for transport to stores, Store $\mathrm{A}=$ store arrival, Store $1=$ store recovery day 1 , Store $2=$ store recovery day 2 , Store $5=$ store recovery day 5 ) showing the mean (diamond), median, upper and lower 25th percentile, and outliers. Letters indicate differences between species within a specific time point where boxes sharing a letter are not significantly different. Asterisks indicate significant differences within a species between different transport stages (post-hoc Tukey, $\mathrm{P}<0.05)$.

Figure 4: (A) $\mathrm{NO}_{3}{ }^{-}(\mathrm{n}=10),(\mathrm{B}) \mathrm{SO}_{4}{ }^{2-}(\mathrm{n}=10),(\mathrm{C}) \mathrm{Cl}^{-}(\mathrm{n}=10)$ and (D) $\mathrm{PO}_{4}{ }^{3-}(\mathrm{n}=30)$ through the transport stages (WS A=wholesaler arrival, WS $1=$ wholesaler recovery day 1 , WS $2=$ wholesaler recovery day 2 , WS $5=$ wholesaler recovery day $5, \mathrm{P}=$ packing for transport to stores, Store $\mathrm{A}=$ store arrival, Store $1=$ store recovery day 1 , Store $2=$ store recovery day 2 , Store $5=$ store recovery day 5 ) showing the mean (diamond), median, upper and lower 25 th percentile, and outliers. (A-C) Letters indicate differences between species within a specific time point where boxes sharing a letter are not significantly different. Asterisks indicate significant differences within a species between different transport stages. (D) Letters indicate differences between time points where boxes sharing a letter are not significantly different. (post-hoc Tukey, $\mathrm{P}<0.05$ ). Figure 5: (A) $\mathrm{Na}^{+}(\mathrm{n}=30),(\mathrm{B}) \mathrm{Ca}^{2+}(\mathrm{n}=10),(\mathrm{C}) \mathrm{K}^{+}(\mathrm{n}=10)$ and (D) $\mathrm{Mg}^{2+}(\mathrm{n}=10)$ through the transport stages (WS A=wholesaler arrival, WS $1=$ wholesaler recovery day 1 , WS $2=$ wholesaler recovery day 2 , WS $5=$ wholesaler recovery day $5, \mathrm{P}=$ packing for transport to stores, Store $\mathrm{A}=$ store arrival, Store $1=$ store recovery day 1 , Store $2=$ store recovery day 2 , Store $5=$ store recovery day 5 ) and species showing the mean (diamond), median, upper and lower 25th percentile, and outliers. (A) Letters indicate differences between time points where boxes sharing a letter are not significantly different. (B) Asterisks indicate significant difference within a species between different transport stages. (C-D) Letters indicate differences between species (post-hoc Tukey, $\mathrm{P}<0.05$ ).

Figure 6: Presence of (A) Aeromonas sp. (\%), (B) Pseudomonas sp. (\%), (C) Mycobacterium sp. (\%) through the transport, $\mathrm{n}=30$. Letters indicate significant difference between transport stages where bars sharing a letter are not significantly different (post-hoc Tukey, $\mathrm{P}<0.05$ ). 
Figure 7: Neon tetra behaviour, (A) crowding behaviour (\%), (B) occurrence of group formation and

901 (WS A=wholesaler arrival, WS $1=$ wholesaler recovery day 1, WS 2= wholesaler recovery day 2, WS

$9025=$ wholesaler recovery day $5, \mathrm{P}=$ packing for transport to stores, Store $\mathrm{A}=$ store arrival, Store $1=$ store

903 recovery day 1 , Store $2=$ store recovery day 2 , Store $5=$ store recovery day 5 ) showing the mean (diamond), median, upper and lower 25 th percentile, and outliers, $n=10$. Letters indicate differences between time points where boxes sharing a letter are not significantly different (post-hoc Tukey, $\mathrm{P}<0.05)$.

Figure 8: Erratic swimming behaviour in oranda through the transport stages (WS A=wholesaler arrival, WS $1=$ wholesaler recovery day 1 , WS $2=$ wholesaler recovery day 2 , WS $5=$ wholesaler recovery day $5, \mathrm{P}=$ packing for transport to stores, Store $\mathrm{A}=$ store arrival, Store $1=$ store recovery day 1 , Store $2=$ store recovery day 2 , Store $5=$ store recovery day 5 ) showing the mean (diamond), median, upper and lower 25 th percentile, and outliers, $n=10$. Letters indicate differences between time points where boxes sharing a letter are not significantly different (post-hoc Tukey, $\mathrm{P}<0.05$ ).

913 Figure 9: Variatus platy behaviour, occurrence of (A) erratic swimming, (B) biting and (C) freezing 914 through the transport stages (WS $1=$ wholesaler recovery day 1, WS $2=$ wholesaler recovery day 2, 915 WS $5=$ wholesaler recovery day $5, \mathrm{P}=$ packing for transport to stores, Store $1=$ store recovery day 1 , 916 Store $2=$ store recovery day 2 , Store $5=$ store recovery day 5 ) showing the mean (diamond), median, 917 upper and lower 25th percentile, and outliers, $n=10$. Letters indicate differences between time points where boxes sharing a letter are not significantly different (post-hoc Tukey, $\mathrm{P}<0.05$ ).

Figure 10: Oranda eye colour by the presence of Mycobacterium sp. showing the mean (diamond), median, upper and lower 25th percentile, and outliers, $n=10$. Asterisks indicate difference (post-hoc Tukey, $\mathrm{P}<0.05)$. 


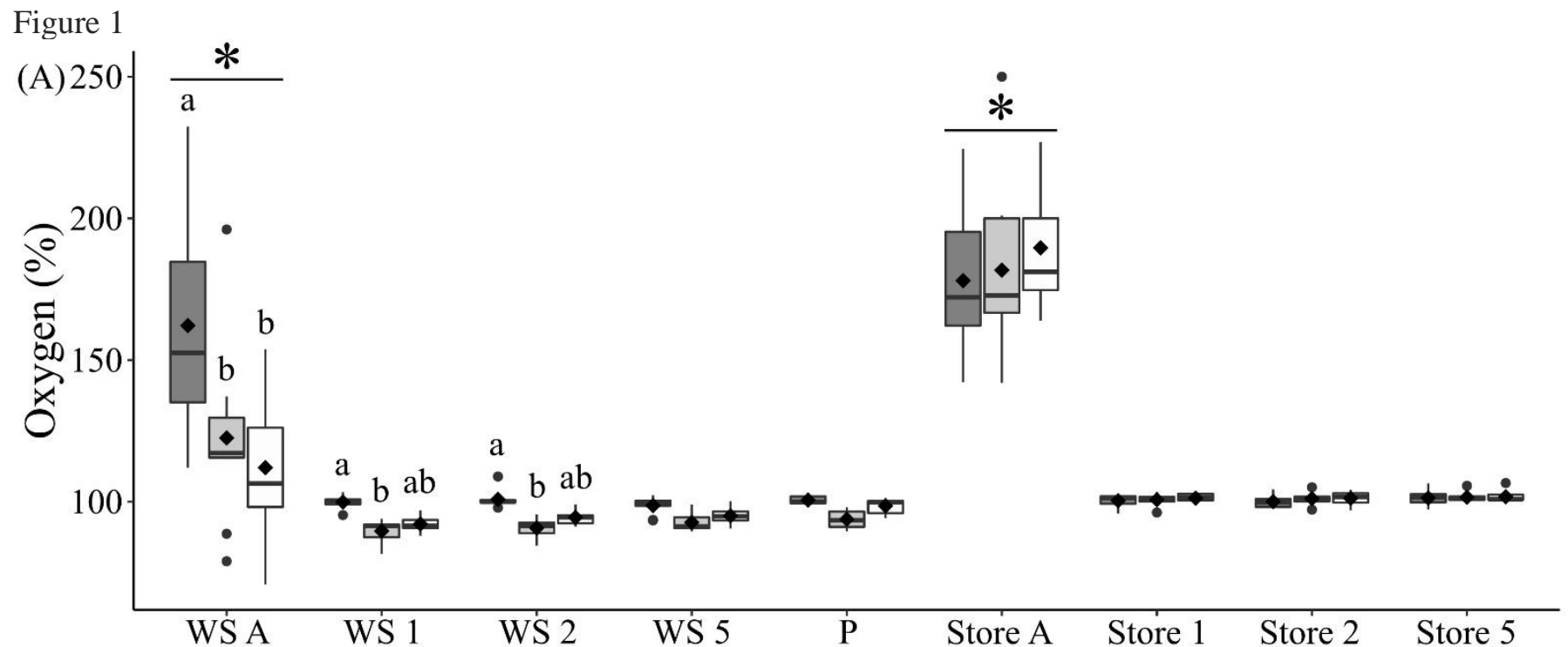

\section{Species}

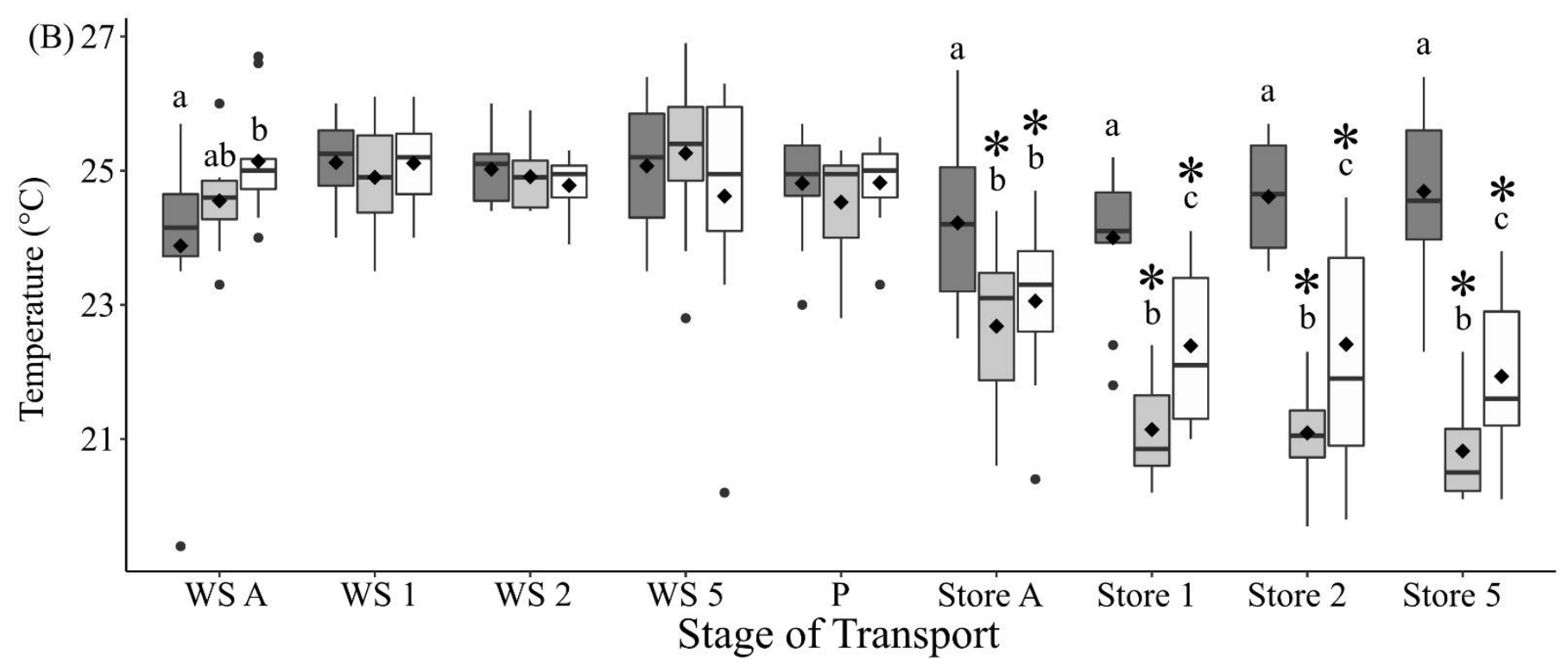

$\square$ Neon tetra

$\square$ Oranda

$\square$ Variatus platy 
Figure 2

(A)
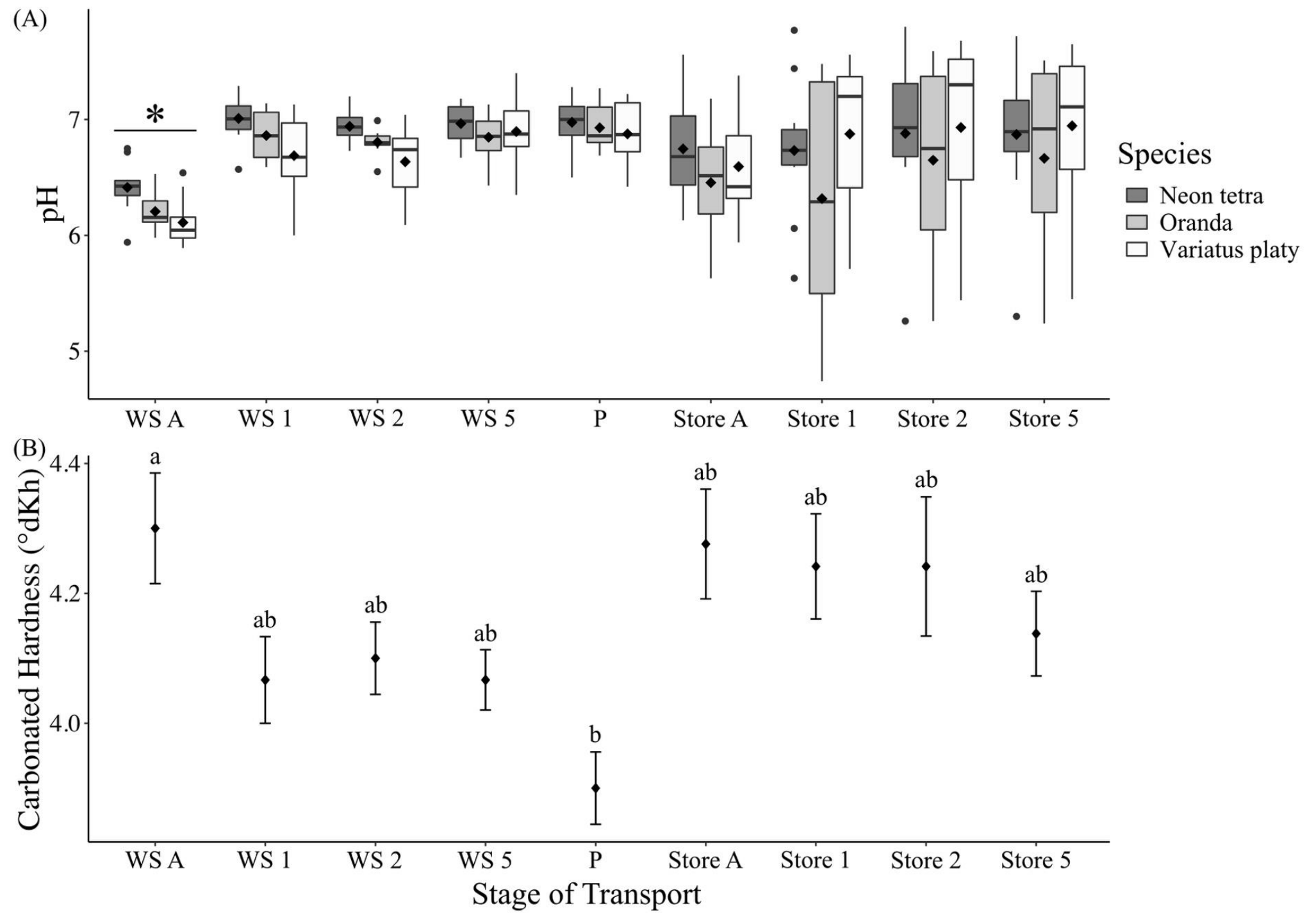
Figure 3
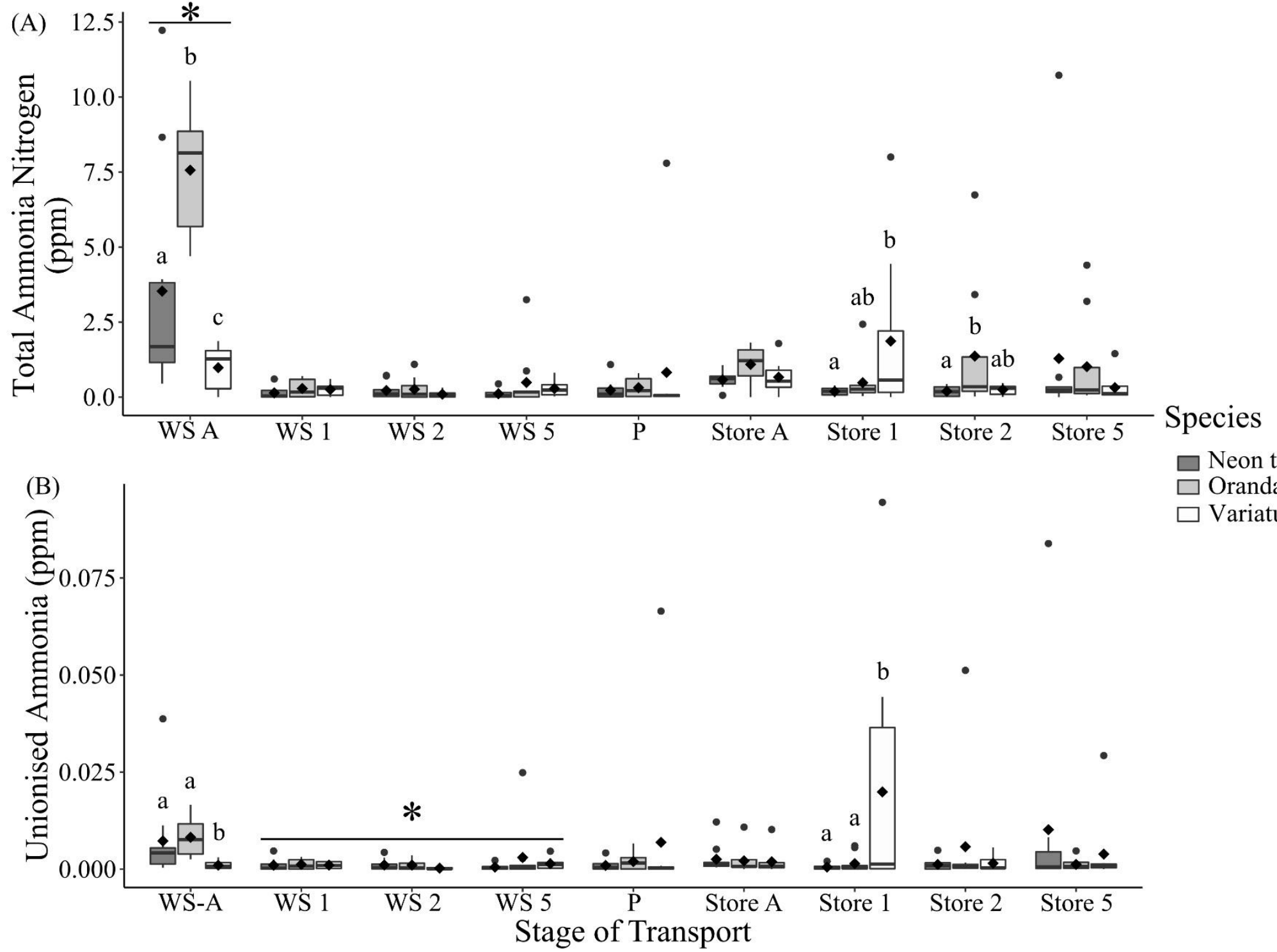

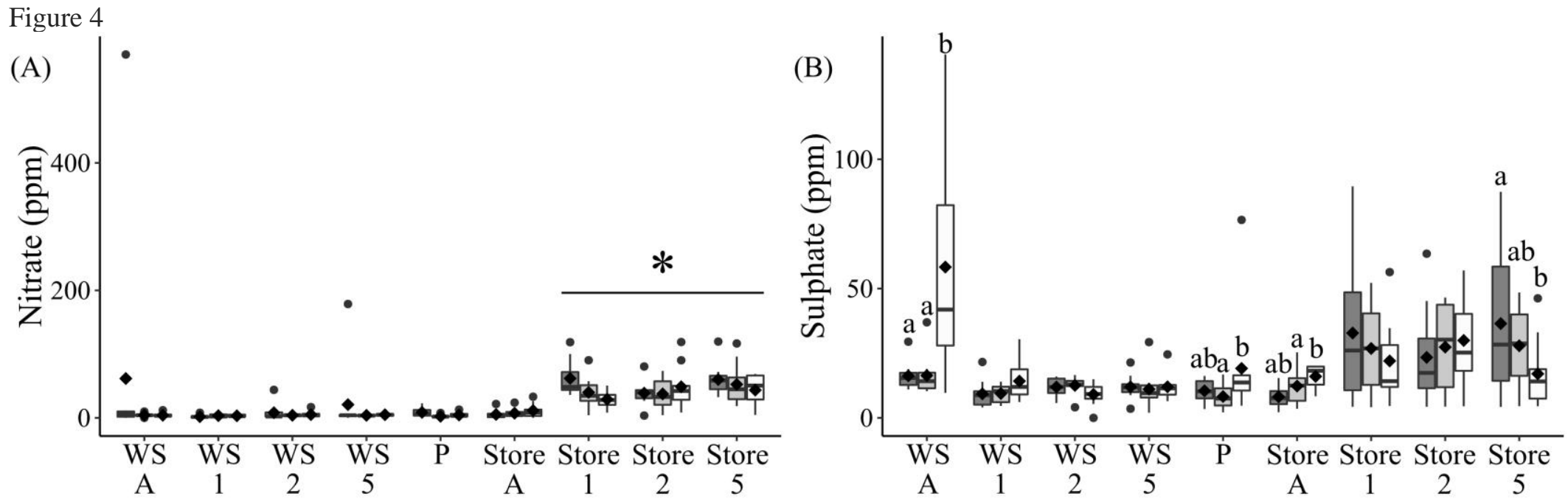

Stage of Transport

Species $\square$ Neon Tetra $\square$ Oranda $\square$ Variatus platy
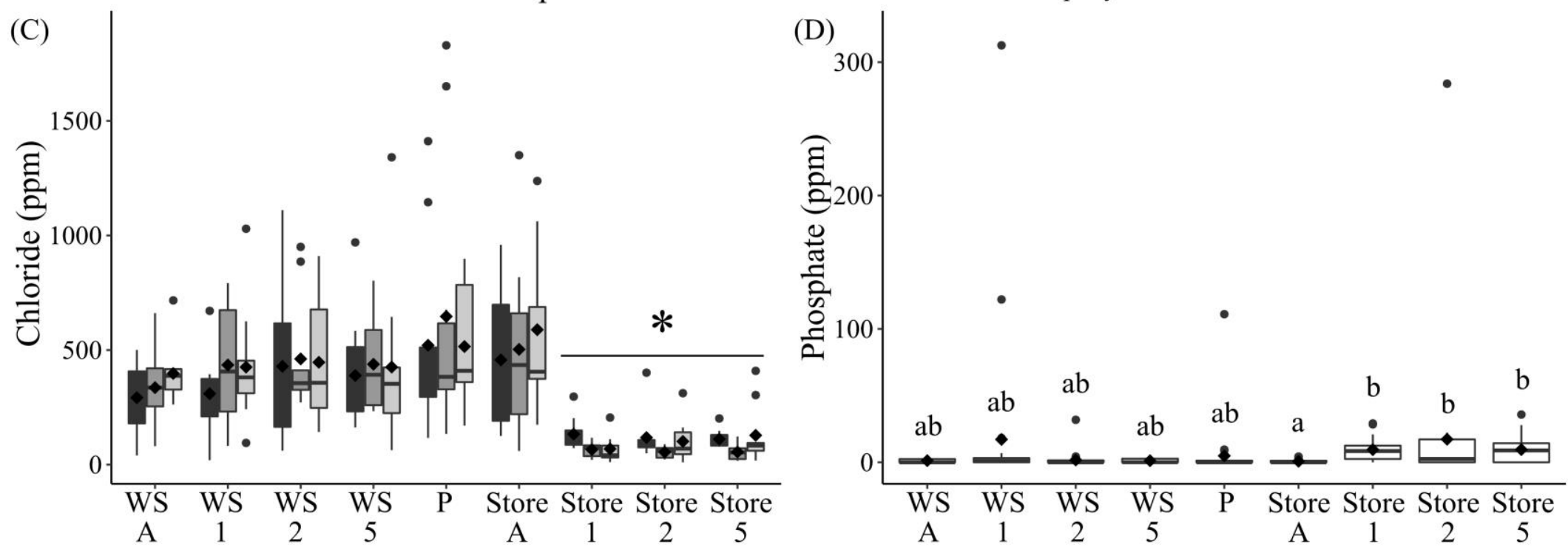
Figure 5
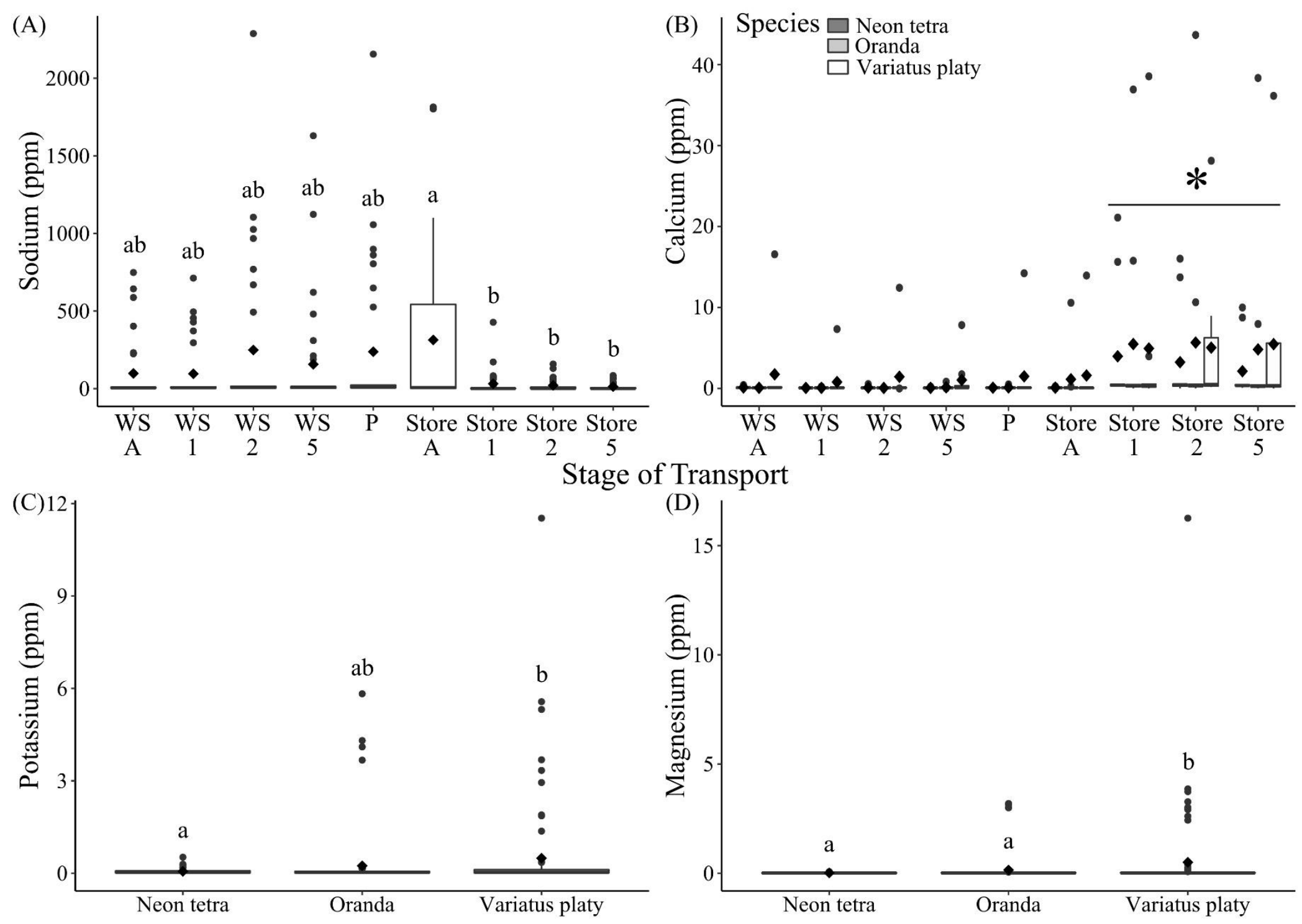

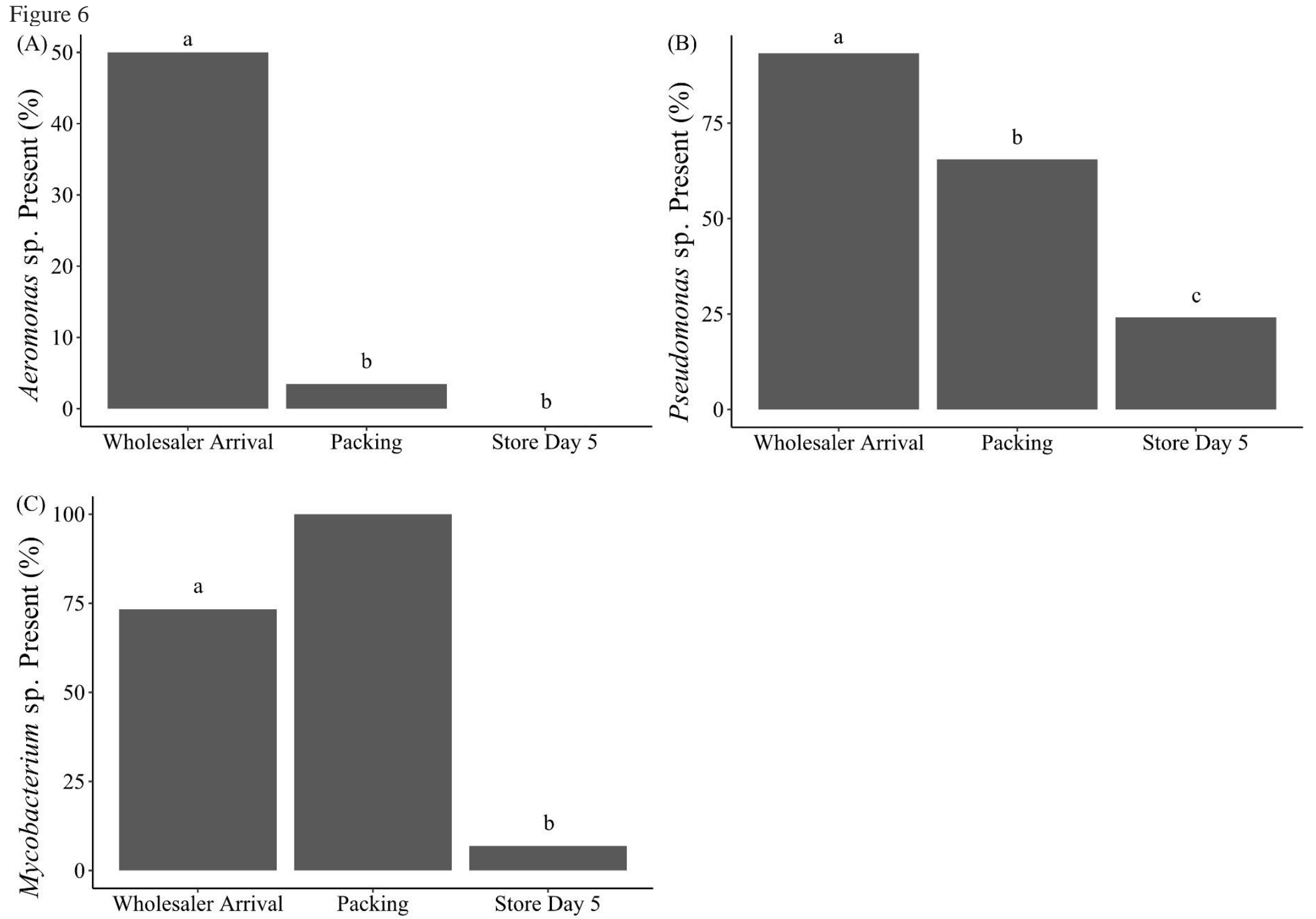

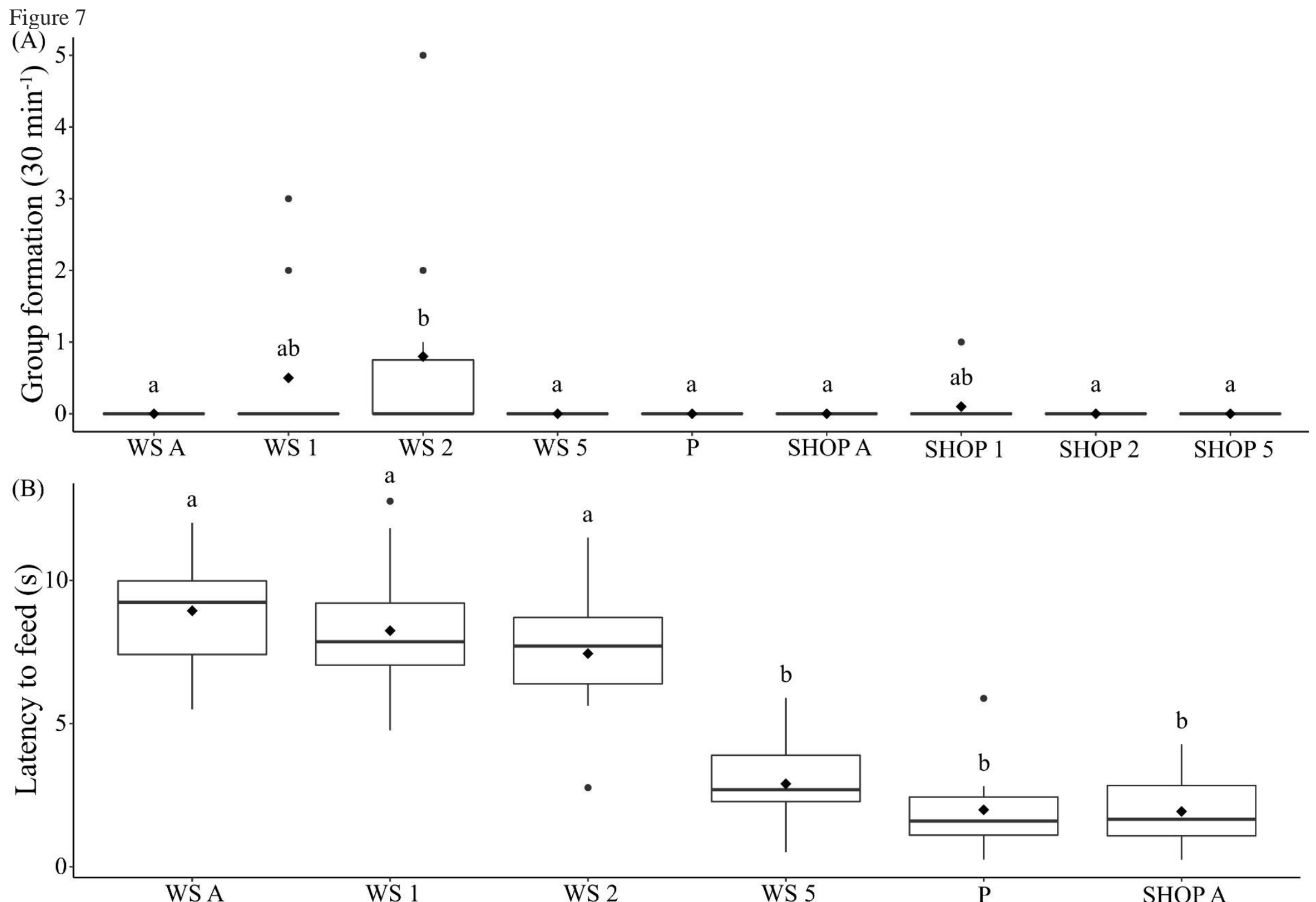

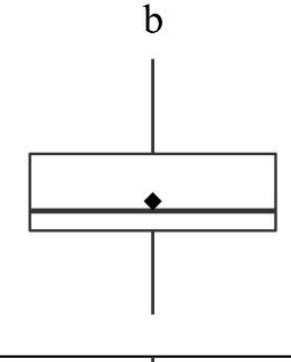
Stage of Transport

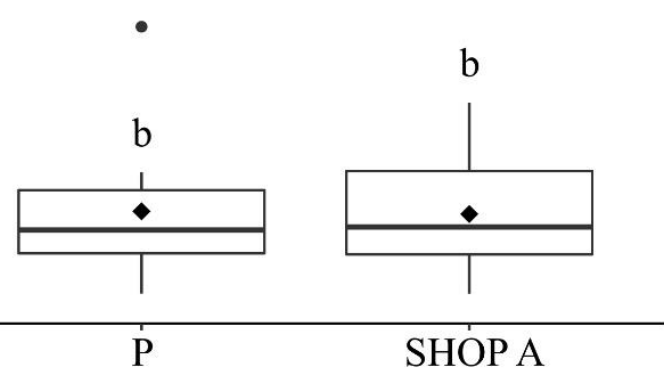


Figure 8

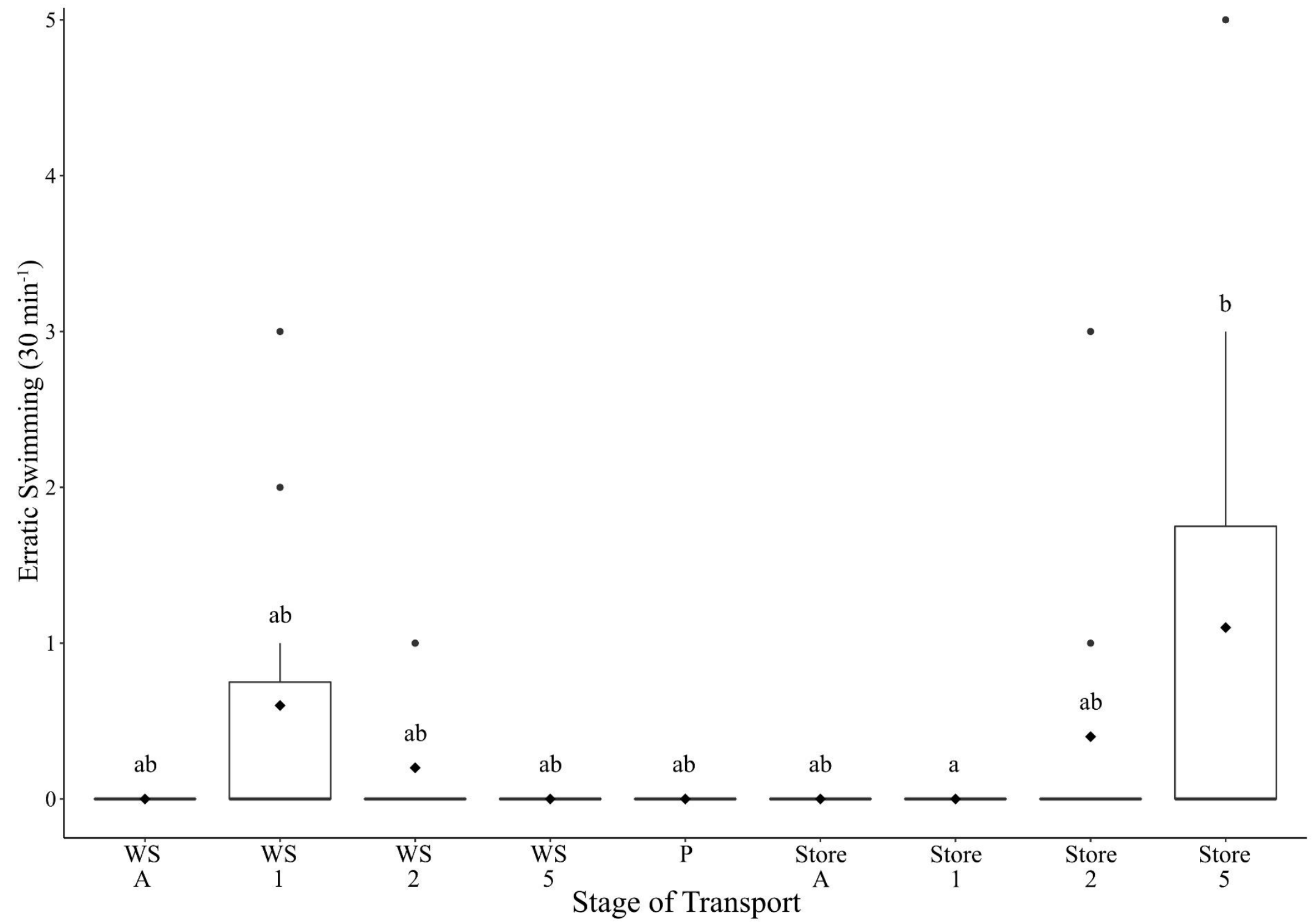



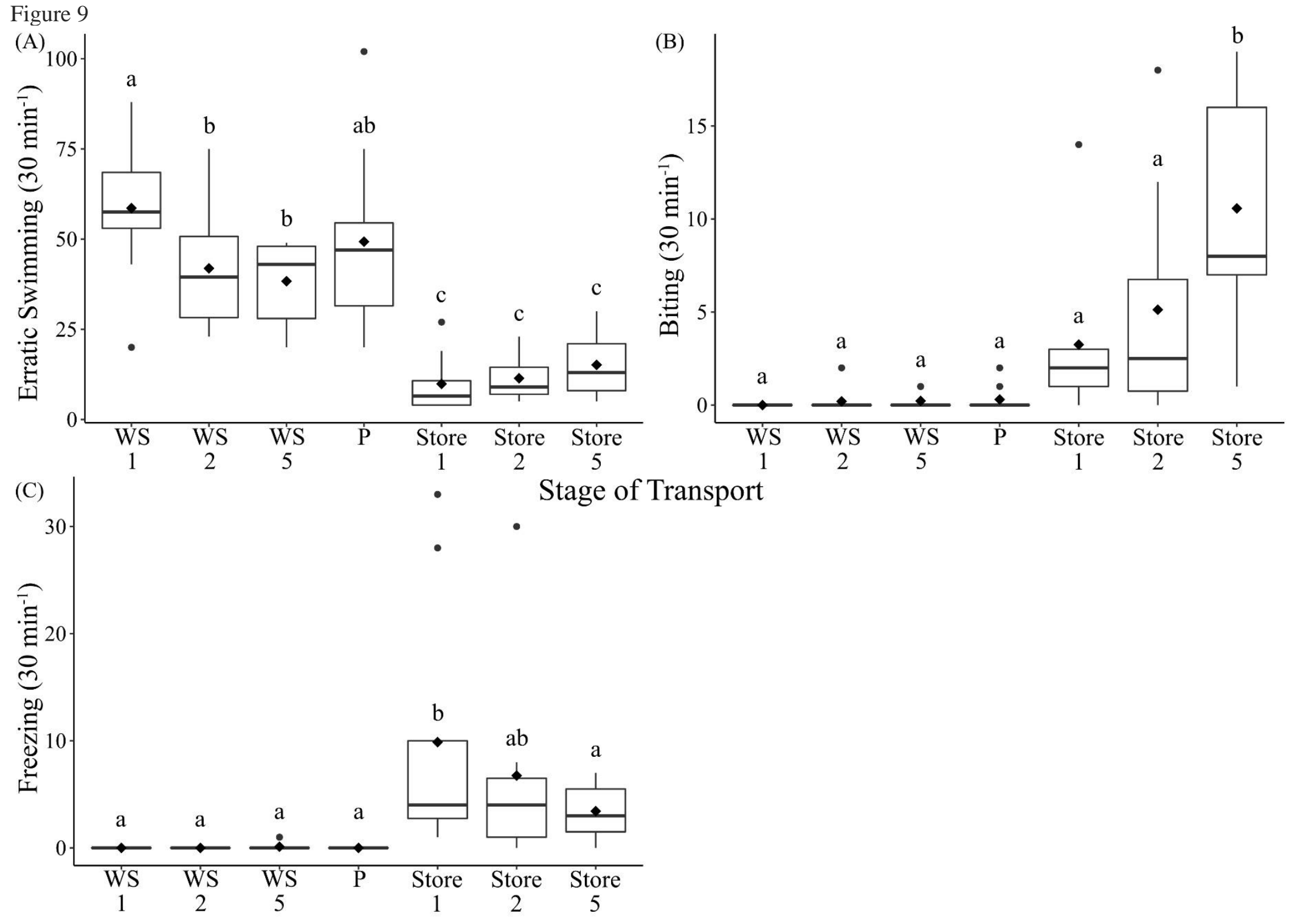


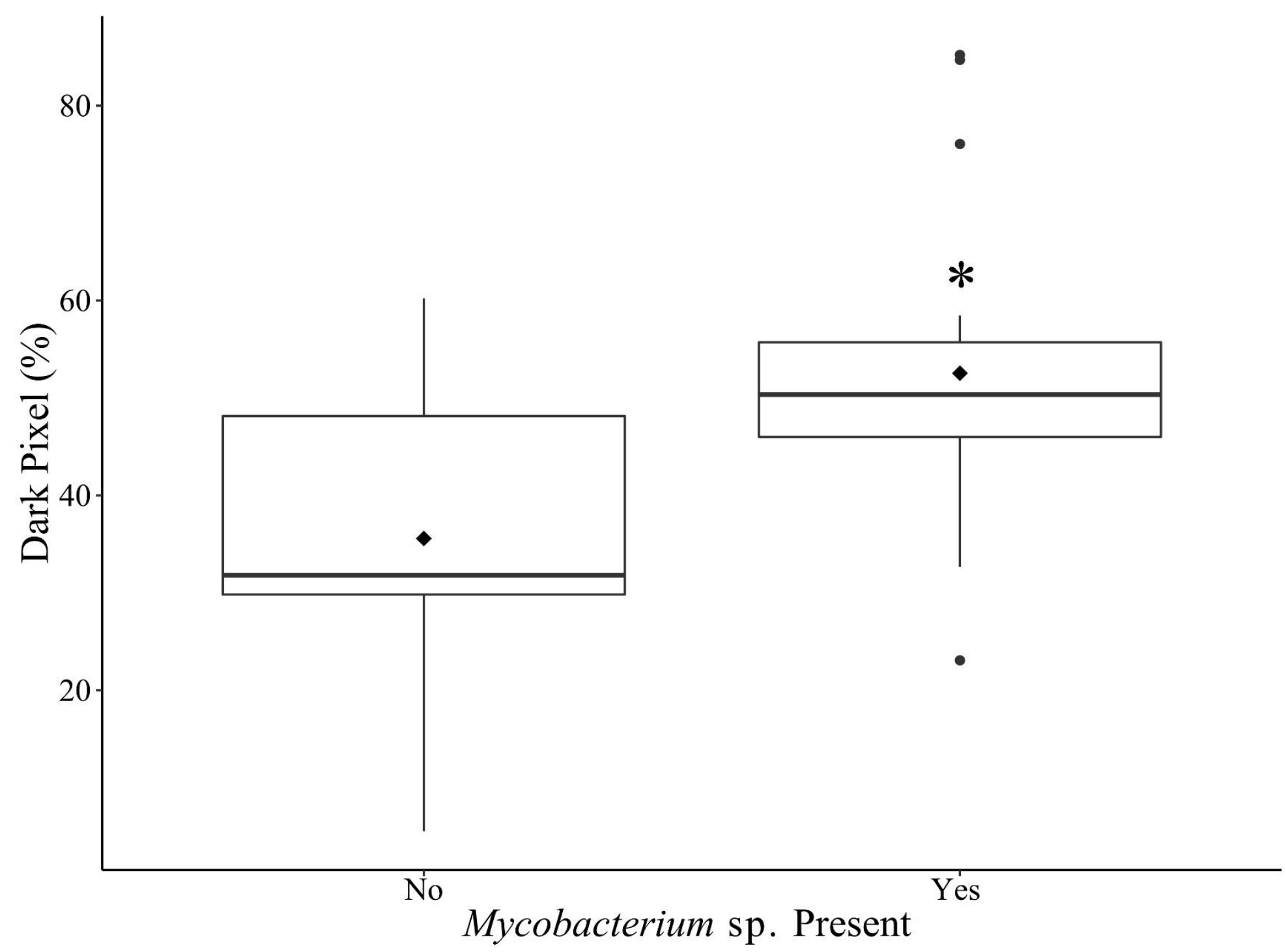




\section{Supplementary Material}

943 Table 1: ANOVA result of best fit model for non-significant behavioural and physiological responses with F values, degrees 944 of freedom (df), and p values.

\begin{tabular}{|c|c|c|}
\hline & & Transport Stage \\
\hline \multicolumn{3}{|l|}{ Neon tetra } \\
\hline & Mortality & $X^{2}=54.667, \mathrm{df}=48, \mathrm{p}=0.236$ \\
\hline & Ventilation rate & Not visible \\
\hline & Body condition & No occurrence \\
\hline & Eye colour & Not visible \\
\hline & Water cortisol concentrations & $\mathrm{F}_{1,4}=0.251, \mathrm{p}=0.642$ \\
\hline & Crowding & $\mathrm{F}_{6,44}=0.028, \mathrm{p}=0.999$ \\
\hline & Gasping & No occurrence \\
\hline & Erratic swimming & Not visible \\
\hline & Freezing & Not visible \\
\hline & Biting & Not visible \\
\hline \multicolumn{3}{|l|}{ Oranda } \\
\hline & Mortality & $X^{2}=16.029, \mathrm{df}=16, \mathrm{p}=0.451$ \\
\hline & Ventilation rate & $\mathrm{F}_{7,41}=1.003, \mathrm{p}=0.612$ \\
\hline & Body condition & $\mathrm{F}_{8,62}=1, \mathrm{p}=0.612$ \\
\hline & Eye colour & $\mathrm{F}_{3,19}=1.806, \mathrm{p}=0.495$ \\
\hline & Water cortisol concentrations & $\mathrm{F}_{1,4}=1.198, \mathrm{p}=0.612$ \\
\hline
\end{tabular}




\begin{tabular}{|c|c|c|}
\hline & Latency to feed & $\mathrm{F}_{1,5}=0.511, \mathrm{p}=0.765$ \\
\hline & Crowding & $\mathrm{F}_{1,4}=1.88, \mathrm{p}=0.242$ \\
\hline & Group formation & No occurrence \\
\hline & Gasping & $\mathrm{F}_{1,2}=14.69, \mathrm{p}=0.093$ \\
\hline & Freezing & No occurrence \\
\hline & Biting & No occurrence \\
\hline Variatus platy & & \\
\hline & Mortality & $X^{2}=63.358, \mathrm{df}=64, \mathrm{p}=0.499$ \\
\hline & Ventilation rate & $\mathrm{F}_{7,41}=1.003, \mathrm{p}=0.612$ \\
\hline & Body condition & $\mathrm{F}_{8,62}=1, \mathrm{p}=0.816$ \\
\hline & Eye colour & $\mathrm{F}_{2,12}=0.259, \mathrm{p}=0.776$ \\
\hline & Water cortisol concentrations & $\mathrm{F}_{1,4}=1.06, \mathrm{p}=0.816$ \\
\hline & Latency to feed & $\mathrm{F}_{1,5}=2.245, \mathrm{p}=0.077$ \\
\hline & Crowding & $\mathrm{F}_{1,1}=0.025, \mathrm{p}=0.899$ \\
\hline & Group formation & No occurrence \\
\hline & Gasping & No occurrence \\
\hline
\end{tabular}

